\title{
Long-term greenhouse gas measurements from aircraft
}

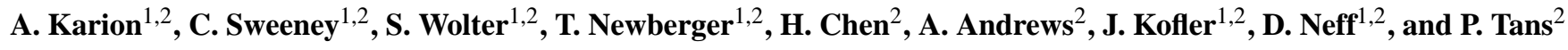 \\ ${ }^{1}$ Cooperative Institute for Research in Environmental Sciences, University of Colorado, Boulder, Colorado, USA \\ ${ }^{2}$ NOAA Earth System Research Laboratory, Boulder, Colorado, USA \\ Correspondence to: A. Karion (anna.karion@noaa.gov)
}

Received: 31 August 2012 - Published in Atmos. Meas. Tech. Discuss.: 2 October 2012

Revised: 7 February 2013 - Accepted: 11 February 2013 - Published: 1 March 2013

\begin{abstract}
In March 2009 the NOAA/ESRL/GMD Carbon Cycle and Greenhouse Gases Group collaborated with the US Coast Guard (USCG) to establish the Alaska Coast Guard (ACG) sampling site, a unique addition to NOAA's atmospheric monitoring network. This collaboration takes advantage of USCG bi-weekly Arctic Domain Awareness (ADA) flights, conducted with Hercules C-130 aircraft from March to November each year. Flights typically last $8 \mathrm{~h}$ and cover a large area, traveling from Kodiak up to Barrow, Alaska, with altitude profiles near the coast and in the interior. NOAA instrumentation on each flight includes a flask sampling system, a continuous cavity ringdown spectroscopy (CRDS) carbon dioxide $\left(\mathrm{CO}_{2}\right)$ /methane $\left(\mathrm{CH}_{4}\right)$ /carbon monoxide $(\mathrm{CO})$ /water vapor $\left(\mathrm{H}_{2} \mathrm{O}\right)$ analyzer, a continuous ozone analyzer, and an ambient temperature and humidity sensor. Air samples collected in flight are analyzed at NOAA/ESRL for the major greenhouse gases and a variety of halocarbons and hydrocarbons that influence climate, stratospheric ozone, and air quality.

We describe the overall system for making accurate greenhouse gas measurements using a CRDS analyzer on an aircraft with minimal operator interaction and present an assessment of analyzer performance over a three-year period. Overall analytical uncertainty of CRDS measurements in 2011 is estimated to be $0.15 \mathrm{ppm}, 1.4 \mathrm{ppb}$, and $5 \mathrm{ppb}$ for $\mathrm{CO}_{2}$, $\mathrm{CH}_{4}$, and $\mathrm{CO}$, respectively, considering short-term precision, calibration uncertainties, and water vapor correction uncertainty. The stability of the CRDS analyzer over a sevenmonth deployment period is better than $0.15 \mathrm{ppm}, 2 \mathrm{ppb}$, and $4 \mathrm{ppb}$ for $\mathrm{CO}_{2}, \mathrm{CH}_{4}$, and $\mathrm{CO}$, respectively, based on differences of on-board reference tank measurements from a laboratory calibration performed prior to deployment. This stability is not affected by variation in pressure or temperature during flight. We conclude that the uncertainty reported for
\end{abstract}

our measurements would not be significantly affected if the measurements were made without in-flight calibrations, provided ground calibrations and testing were performed regularly. Comparisons between in situ CRDS measurements and flask measurements are consistent with expected measurement uncertainties for $\mathrm{CH}_{4}$ and $\mathrm{CO}$, but differences are larger than expected for $\mathrm{CO}_{2}$. Biases and standard deviations of comparisons with flask samples suggest that atmospheric variability, flask-to-flask variability, and possible flask sampling biases may be driving the observed flask versus in situ $\mathrm{CO}_{2}$ differences rather than the CRDS measurements.

\section{Introduction}

Quantifying greenhouse gas (GHG) emissions in the Arctic is crucial for understanding changes in the carbon cycle because of their large potential impact on the earth's warming. As organic carbon stored in thawing Arctic permafrost resurfaces, a portion of it will be emitted as either methane $\left(\mathrm{CH}_{4}\right)$ or carbon dioxide $\left(\mathrm{CO}_{2}\right)$. Because methane's global warming potential is more than 25 times greater than that of $\mathrm{CO}_{2}$ for a 100-yr time horizon (Forster, 2007), and because Arctic stores of organic carbon are estimated to be larger than the total carbon from anthropogenic emissions since the beginning of the industrial era, Arctic $\mathrm{CH}_{4}$ emissions will potentially create an important feedback mechanism for climate change (McGuire et al., 2009; Jorgenson et al., 2001; Keyser et al., 2000; O'Connor et al., 2010). An understanding of how the permafrost thaw evolves is of paramount importance.

In order to better understand the cycling of $\mathrm{CO}_{2}$ and $\mathrm{CH}_{4}$ in the Arctic, the NOAA Earth System Research Laboratory (ESRL) Global Monitoring Division (GMD) aircraft program collaborated with the US Coast Guard (USCG) to 
establish a new airborne sampling program over Alaska. The USCG Air Station Kodiak regularly conducts Arctic Domain Awareness (ADA) flights, using their fleet of four C-130 Hercules aircraft for routine monitoring of the melting sea ice and changing conditions around Alaska. The NOAA aircraft group collaborated with the USCG to install an atmospheric sampling payload aboard the aircraft slated for these survey missions. Data from these flights are given the site code "ACG" for Alaska Coast Guard.

ACG sampling complements existing Alaskan NOAA ground stations at Barrow (BRW) and Cold Bay (CBA), and a flask-only aircraft site near Fairbanks (PFA). ACG's highresolution GHG dry mole fraction (moles of a trace gas per mole of dry air) measurements, which include several altitude profiles from the ground to $8 \mathrm{~km}$ on each bi-weekly flight, are a valuable addition to the NOAA global network and to the existing suite of Arctic measurements. In contrast with past aircraft campaigns that focused on Arctic GHG measurements (Harriss et al., 1992, 1994; Conway et al., 1993; Kort et al., 2012; Jacob et al., 2010; Vay et al., 2011), ongoing measurements over multiple years at ACG will enable investigation of both seasonal and inter-annual variability.

ADA flights depart the USCG Air Station on Kodiak Island, Alaska, then typically transect at high altitude over the Alaskan interior to Barrow, where the aircraft either lands or descends to low altitude. The aircraft conducts a low-altitude survey of the coastline west toward Kivalina and then continues back to Kodiak (Fig. 1), with flights typically lasting approximately eight hours. From March to November for three seasons so far (2009-2011), the NOAA aircraft group deployed its observation system on these USCG flights, measuring greenhouse gases and ozone nearly every two weeks, totaling 38 successful flights. The program has just completed its fourth season.

Cavity ring-down spectroscopy (CRDS) instruments for measuring trace gas mole fractions (Crosson, 2008) have only been commercially available for a few years, but have already been integrated into analysis systems at various GHG measurement sites around the world. In the CRDS technique, laser light at a specific wavelength is tuned to the species of trace gas being measured and emitted into an optical cavity with an effective optical path length of 15-20 km (achieved using highly reflective mirrors). The instrument software measures the time constant of the decay (ring-down) of the light intensity as it is absorbed by the target gas in the optical cell (also called the cavity) after the laser is turned off. Picarro CRDS instruments use a high-precision wavelength monitor along with control of pressure and temperature in the measurement cell to achieve high precision measurements of trace gases. In comparison to non-dispersive infrared (NDIR) instruments, CRDS instruments have been shown to be more stable over short and long time scales, requiring less frequent calibration. CRDS instruments are also very linear in their response, requiring fewer standard gases for calibration. One reason for the measurement stability is that the instrument maintains tight control of temperature and pressure in the measurement cell, allowing simple deployment in the field without additional environmental controls.

Numerous scientific studies that used CRDS analyzers to make $\mathrm{CO}_{2}$ and $\mathrm{CH}_{4}$ measurements at stationary ground and tower sites have demonstrated these advantages (Miles et al., 2012; Winderlich et al., 2010; Richardson et al., 2012). Chen et al. (2010) describe the use of a CRDS analyzer aboard an aircraft during the Balanco Atmosferico Regional de Carbono na Amazonia (BARCA) campaign, and show that their results compare favorably with an NDIR analyzer deployed on the same aircraft. CRDS analyzers have been used in light aircraft to investigate urban $\mathrm{CO}_{2}$ and $\mathrm{CH}_{4}$ emissions as well (Turnbull et al., 2011; Mays et al., 2009; Cambaliza et al., 2011). Other non-CRDS (usually NDIR) techniques for $\mathrm{CO}_{2}$ and $\mathrm{CH}_{4}$ measurement have been used extensively in aircraft as well, usually in the framework of a campaign in which a scientist or engineer monitors instrument performance either in flight or pre- and post-flight (Daube et al., 2002; Martins et al., 2009; Miller et al., 2007; Xueref-Remy et al., 2011; Paris et al., 2008; Wofsy et al., 2011; O'Shea et al., 2013). NDIR $\mathrm{CO}_{2}$ analyzers have also been used on aircraft making regular (non-campaign) measurements: Machida et al. (2008) have successfully deployed an NDIR analyzer on Japan Airlines commercial aircraft with no operator present, and Chen et al. (2012b) and Biraud et al. (2012) have done so on light aircraft making regular profiles with NDIR analyzers over long periods of time.

This paper outlines our methodology for making highquality GHG measurements in the field in a monitoring mode, in which the instrumentation must run semiautonomously for long periods of time, and in which a scientist is generally not in the field and available to oversee the operation of the various instruments. We describe advantages and disadvantages of the system and show results, including comparisons between the continuous analyzer and flask measurements.

\section{Methods}

The system, designed for easy installation on the C-130 aircraft, is strapped to a pallet that is loaded and unloaded from the aircraft for each flight (Fig. 2, left panel). Although there have been slight changes made to the system over the years, the basic measurement components of the system are the following: (1) a continuous in situ $\mathrm{CO}_{2} / \mathrm{CH}_{4} / \mathrm{CO} / \mathrm{H}_{2} \mathrm{O}$ analyzer, (2) a continuous ozone monitor, (3) a flask system for collecting whole air samples, (4) a temperature and relative humidity sensor, and (5) GPS measurements of location and time for measurement synchronization. Details of each instrument (excepting the ozone monitor) and its measurements are described below. In this paper, we have chosen not to describe the ozone measurements in detail, focusing 

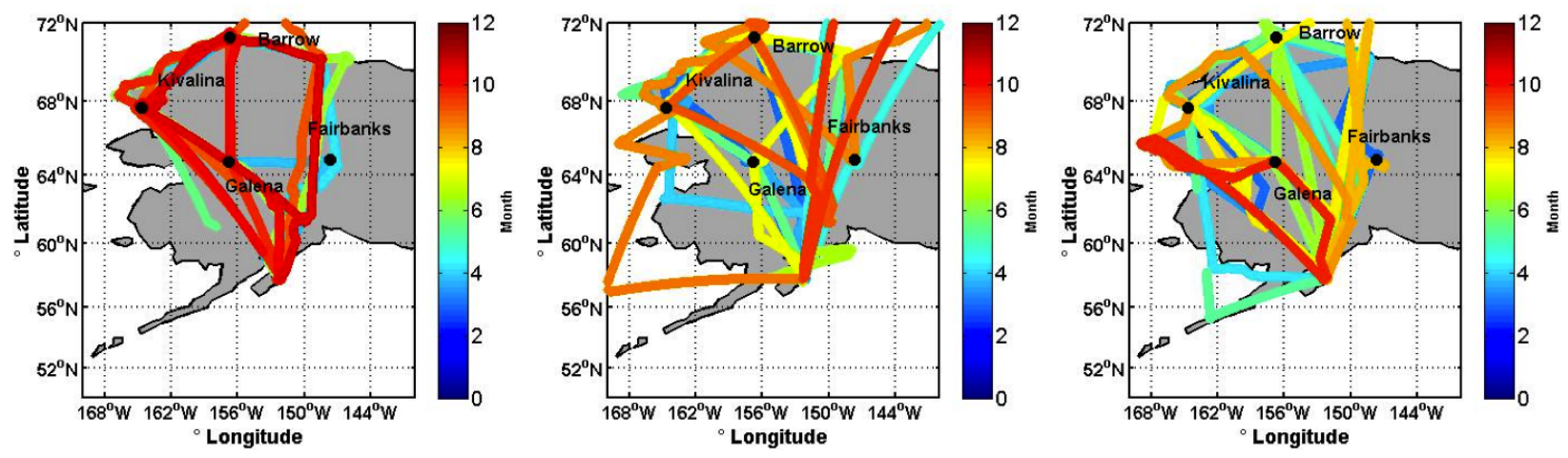

Fig. 1. Flight paths from the three complete seasons of GHG sampling: 2009 (left panel), 2010 (center panel), and 2011 (right panel). The color of the flight path corresponds to the month of the flight.
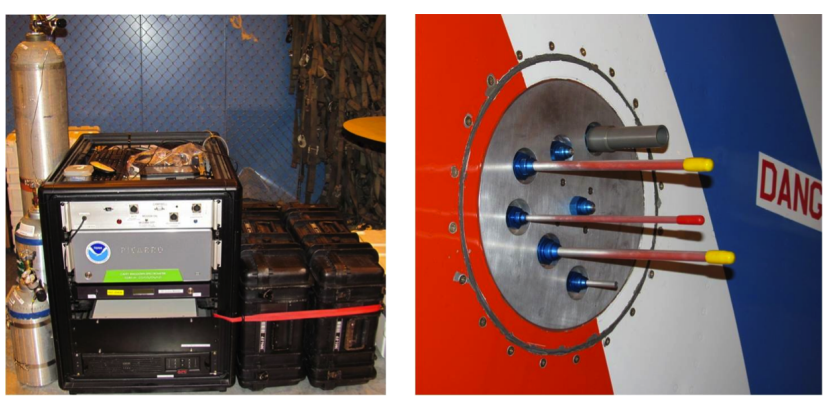

Fig. 2. NOAA equipment pallet for USCG C-130: three reference gas cylinders, instrument rack, and two Programmable Flask Packages (PFPs) (left). Window replacement inlet plate (external view) (right).

instead primarily on the operation and performance of the in situ continuous GHG analyzer. Ozone is measured by UV absorbance (2B Technologies), with further details on the tropospheric ozone measurements from aircraft found at http://www.esrl.noaa.gov/gmd/ozwv/aircraft/aircraft.html.

\subsection{Inlets}

The inlets delivering external air to the instrumentation are mounted through an aluminum plate that replaces a circular window on the fuselage of the aircraft forward of the propellers; the inlets extend approximately $0.2 \mathrm{~m}$ from the aircraft body (Fig. 2, right panel). External inlets are capped with plastic covers when not in use. There are three separate inlet lines, one for each of three systems (continuous GHG analyzer (CRDS), ozone monitor, and flask system). The continuous CRDS GHG analyzer pulls air through a $0.635 \mathrm{~cm}\left(1 / 4^{\prime \prime}\right)$ outer diameter (OD) Kynar inlet, while the flask system pulls air through a separate $0.95 \mathrm{~cm}\left(3 / 8^{\prime \prime}\right) \mathrm{Ky}-$ nar inlet line. The ozone monitor pulls its sample air through a $0.635 \mathrm{~cm}\left(1 / 4^{\prime \prime}\right)$ OD Teflon line. Kynar has historically been used as the sample inlet line material for all NOAA/ESRL aircraft program flask sampling, and has been previously tested for contamination of trace gases measured in the whole air flask samples and by the CRDS system.

The inlets extending from the aircraft body were initially (i.e., in the 2009 and 2010 seasons) aluminum tubing that was larger than the Kynar inlet line in diameter and installed so that the Kynar line was passed through the inside of the aluminum tubing, making a single continuous length from the analyzers to the outside of the aircraft. In 2011, a new inlet system was installed for the CRDS and flask systems, in which the sample passed through a $0.3 \mathrm{~m}$ length of aluminum alloy 6061 tubing and was connected to the Kynar line inside the aircraft. This change was made to make the removal and re-installation of the inlets simpler. Flight $\mathrm{CO}_{2}$ measurements from the continuous CRDS analyzer using the new inlets began to show $\mathrm{CO}_{2}$ depletion relative to the flasks after the first two flights, which was initially $\sim 0.2 \mathrm{ppm}$. By June 2011 the offsets were closer to $0.5 \mathrm{ppm}$ on average, but not consistent (some flask comparisons showed no offset, while some indicated depletion of $1 \mathrm{ppm}$ or more in the CRDS sampling line). Subsequently, the on-site technician tested the inlets by supplying standard gas to the CRDS analyzer through the inlets (i.e., following the same path as the sample from the outside of the aircraft) and found that $\mathrm{CO}_{2}$ was depleted up to $2 \mathrm{ppm}$ while passing through the $0.3 \mathrm{~m}$ section of aluminum tubing prior to entering the Kynar line. The depletion became smaller as the inlet was flushed with dry air. $\mathrm{CH}_{4}$ and $\mathrm{CO}$ were not affected. Because there was no robust way to determine the effect on the flight measurements, the decision was made to flag all the $\mathrm{CO}_{2}$ data from the flights with these inlets as unusable. The inlets were replaced with stainless steel versions, and are now regularly tested as described above. Laboratory tests performed after the return of the aluminum inlets showed that the flask sample air, although also passing through an aluminum inlet, was not significantly affected because of the much higher flow rates ( $>10$ standard liters per minute (SLPM) versus 0.28 SLPM for the CRDS system). We attribute the $\mathrm{CO}_{2}$ depletion to degradation of the aluminum 6061 when exposed to humid marine air in Kodiak. 


\subsection{Continuous $\mathrm{CO}_{2} / \mathrm{CH}_{4} / \mathrm{CO} / \mathrm{H}_{2} \mathrm{O}$}

A CRDS analyzer (Picarro, Inc.) is the central component of the analysis system aboard the ACG flights. In the 2009 and 2010 seasons, a G1301-m series 3-species flight analyzer was used to measure $\mathrm{CO}_{2}, \mathrm{CH}_{4}$, and water vapor (two different units, serial numbers CFADS08 and CFADS09, respectively). Since the beginning of the 2011 season, a newer G2401-m series 4-species analyzer (CFKBDS2007) has been flown, adding continuous $\mathrm{CO}$ measurements. The measurements are calibrated and expressed as dry mole fractions. Flight analyzers from Picarro differ from their ground models in two basic ways: first, they have an ambient pressure sensor that provides data used in the analyzer software to adjust the wavelength monitor, and, second, the measurement cell pressure is controlled using the upstream (inlet) proportional valve rather than the downstream (outlet) valve, and a critical orifice is installed downstream of the cavity to maintain a constant mass flow rate. The second difference is discussed in further detail in the following section.

\subsubsection{Plumbing schematic}

A vacuum pump downstream of the CRDS analyzer installed on the C-130 pulls external air through the aircraft inlet and through the analyzer (Fig. 3). Components upstream are carefully evaluated, and care is taken to avoid "dead volumes" and materials that might lead to contamination. A rackmounted control box contains a sample-selection rotary valve (VICI Valco multiport valve, MPV) controlled by a Campbell Scientific CR1000 data logger. The sample enters the aircraft through the inlet line into the control box, flowing past a pressure sensor $\left(P_{i}\right)$ into one of the ports on the MPV. Three calibration tanks are connected via $0.16 \mathrm{~cm}\left(1 / 16^{\prime \prime}\right)$ OD stainless steel tubing to other ports on the MPV. The $0.16 \mathrm{~cm}$ tubing ensures that there is some pressure drop between the outlet of the tank regulators, set to approximately $150-200 \mathrm{hPa}$ above ambient pressure (2-3 psig), and the inlet of the analyzer, maintaining pressure close to $1000 \mathrm{hPa}$ at the analyzer inlet during calibration periods. Picarro CRDS analyzers are designed to accept inlet air close to or below ambient pressure. Exceeding one atmosphere of pressure by a significant amount (this is dependent on the analyzer) causes instability in the pressure of the analyzer cell. The $\mathrm{C}-130$ cabin is pressurized so regulator delivery pressure does not vary significantly in flight, while sample pressure varies with altitude. There is a brief spike in the cavity pressure when switching between a standard gas and the sample stream, due to the difference in their pressures.

Once a stream is selected by the MPV, the air flows through a short length of $0.3175 \mathrm{~cm}\left(1 / 8^{\prime \prime}\right)$ OD stainless steel tubing past a second pressure sensor $\left(P_{a}\right)$ into the analyzer. Inside the analyzer, a proportional valve controls the flow of air into the analyzer cell, maintaining constant pressure in the cell at $186.7 \pm 0.03 \mathrm{hPa}$ (standard deviation given for

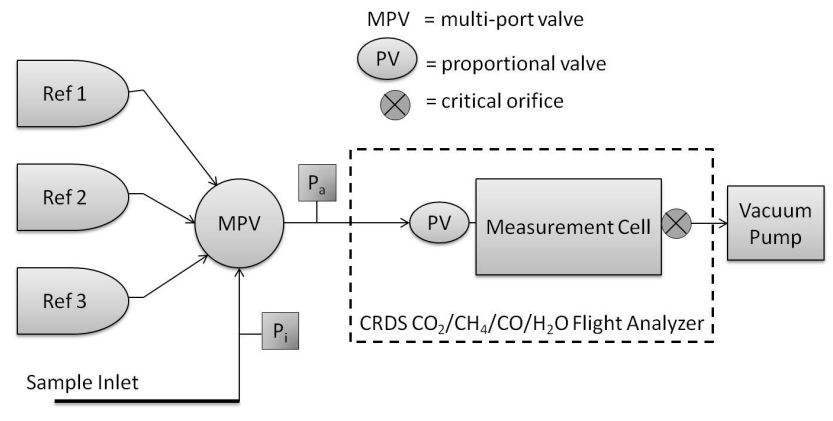

Fig. 3. Schematic diagram of $\mathrm{CO}_{2} / \mathrm{CH}_{4} / \mathrm{CO} / \mathrm{H}_{2} \mathrm{O}$ sampling system on the C-130 aircraft.

G2401 model in the laboratory). Temperature in the cell is also tightly controlled at $45 \pm 0.008^{\circ} \mathrm{C}$.

As directed by the manufacturer, the vacuum pump is connected downstream of the analyzer, and the mass flow rate through the analyzer is determined by the diameter of a critical orifice between the cell and the vacuum pump (i.e., downstream of the cell, Fig. 3). The critical orifice maintains a constant mass flow rate through the analyzer that is independent of ambient pressure (either in the cabin or outside the plane), provided the vacuum pressure downstream of the orifice (between the cavity and the pump) is at least half of the cell pressure. We note that a critical orifice is used in Picarro's flight analyzers only. The non-flight analyzers control cell pressure using a proportional valve at the outlet of the cell, while the inlet proportional valve remains at a constant setting. The main difference in the two designs is that the non-flight analyzers do not maintain a constant mass flow rate through the cell when the inlet pressure varies, while the flight analyzers are designed to do so. Picarro provides a critical orifice with analyzers designed for flight, but different diameter orifices can be used to further reduce the flow rate if needed. At the ACG site, the mass flow rate has varied over time and was 250 standard cubic centimeters per minute ( $\mathrm{sccm}$ ) in 2009 , $350 \mathrm{sccm}$ in 2010, and $280 \mathrm{sccm}$ in 2011 and 2012, depending on the analyzer; a custom orifice was machined for the 2011 analyzer at NOAA with a diameter of approximately $0.051 \mathrm{~cm}$ to achieve the desired flow rate of $280 \mathrm{sccm}$. High flow rates increase the pressure drop upstream of the cavity, reducing the altitude ceiling at which the analyzer can perform. For this reason, in 2010 a custom wide-bore MPV was used to accommodate the higher flow rate, because it was found that the pressure drop through the valve with the standard size ports was too high at altitudes close to $8 \mathrm{~km}$, where the C-130 spends much of its flight time.

The plumbing for the deployment of the CRDS analyzers was designed to be as simple as possible, given that they are to be run autonomously with minimal user interference. The design, however, introduces several trade-offs. First, the standard tank gas is delivered to the analyzer at higher pressure (just over $1000 \mathrm{hPa}$ ) than the sample stream pressure, 
which can be as low as $340 \mathrm{hPa}$ at altitude. Fortunately, the analyzers can stabilize cavity pressure in response to such a pressure change within $10 \mathrm{~s}$. Second, the $\sim 6 \mathrm{~m}$ sample inlet line is not flushed continuously while the analyzer samples from a standard tank. Thus, after every calibration, $\sim 60 \mathrm{~s}$ of data are discarded (corresponding to three flush volumes of the line at sea level), to remove any effects due to pressure changes in the inlet line from the stopped flow as well as the stagnant sample air. Third, the standard gas is delivered to the analyzer dry while the sample air stream is not dried, so measurement uncertainty depends on the uncertainty of the water vapor correction (the water vapor correction is addressed in Sect. 2.2.5).

\subsubsection{Response time}

The transition from wet to dry air leads to long equilibration times between sample and reference gas for both $\mathrm{CO}_{2}$ and $\mathrm{CH}_{4}$. In flight, calibration standards are run through the analyzer for three minutes, with the first minute discarded because of the $\sim 60$ s equilibration time needed to arrive to the within $0.1 \mathrm{ppm}$ of $\mathrm{CO}_{2}$ and $1 \mathrm{ppb}$ of $\mathrm{CH}_{4}$ of the final value. A total of $60 \mathrm{~s}$ of data are discarded after every switch (both from standard to ambient and from ambient to standard). To investigate the cause of this long equilibration time, laboratory tests were conducted with two standard gases containing natural air with different mole fractions of $\mathrm{CO}_{2}$ and $\mathrm{CH}_{4}$, and drying and wetting them alternately. Using the same model G2401-m analyzer (SN CFKBDS2059), it was found that transitioning from $1.4 \%$ to almost $0 \%$ water vapor resulted in a significantly slower $\mathrm{CO}_{2}$ and $\mathrm{CH}_{4}$ response than when transitioning between two dry tanks or two wet tanks containing different $\mathrm{CO}_{2}$ and $\mathrm{CH}_{4}$ mole fractions (Fig. 4). The additional time results in a higher consumption of standards than would be necessary if all incoming air were dried. We note that after $60 \mathrm{~s}$ the bias in the measurement is under $0.1 \mathrm{ppm}$ for $\mathrm{CO}_{2}$ and $1 \mathrm{ppb}$ for $\mathrm{CH}_{4}$. The actual average of 120 more seconds after that is biased by a negligible amount however.

The cause of the long transition time was found to be a long averaging time in the Picarro measurement software for the $\mathrm{CO}_{2}$ and $\mathrm{CH}_{4}$ baselines, and not adsorption of water vapor onto inlet tubing surfaces, as was initially suspected. Water vapor does not have strong resonant absorption lines that directly interfere with the absorption lines used to quantify carbon dioxide and methane, which means that the "crosstalk" between water vapor and the other gases is low. However, there is a small amount of non-resonant broadband absorption from water vapor that affects the baseline absorption loss underlying the analyte absorption lines. The baseline absorption loss is subtracted from the peak absorption loss, and this difference is then used (with an appropriate linear scaling factor) to quantify the mole fractions of the analyte species. The standard instrument software has a $50 \mathrm{~s}$ exponential average on this baseline, which under most conditions leads to a somewhat improved noise performance of the analyte gases. However, under conditions of rapidly changing water vapor concentration, the time response of the analyte gas is degraded due to the fact that the average of the baseline absorption loss tends to lag the actual absorption loss, leading to a transient bias in the measured mole fractions. This bias disappears under steady-state conditions (C. Rella, Picarro, personal communication, 2012). A system software parameter change was made to the laboratory instrument, reducing the averaging time for the response of the measurement baseline for $\mathrm{CO}_{2}$ and $\mathrm{CH}_{4}$, and led to a marked improvement in the analyzer's response to a fast change in water vapor.

To test the new parameter, an experiment was conducted in the laboratory alternating between two streams of the same standard gas: one wet to approximately $1.7 \% \mathrm{H}_{2} \mathrm{O}$, the other dry $\left(0.0006 \% \mathrm{H}_{2} \mathrm{O}\right)$. The parameter adjustment decreased the response time needed to achieve the final value within $0.1 \mathrm{ppm}$ for $\mathrm{CO}_{2}$ and $2 \mathrm{ppb}$ for $\mathrm{CH}_{4}$ by a factor of two, from $40 \mathrm{~s}$ to $20 \mathrm{~s}$ (Fig. 5). The short-term precision of the laboratory analyzer was slightly degraded (the standard deviation increased by $\sim 10 \%$ ) with this change. This software parameter will be adjusted on the flight instrument as well to allow for shorter calibration times and to better capture rapid gradients in water vapor and $\mathrm{CO}_{2}, \mathrm{CH}_{4}$, and $\mathrm{CO}$ that often exist in profiles between the boundary layer and the free troposphere or the free troposphere and the stratosphere.

The response time of the analyzer currently deployed at ACG (Picarro model G2401-m SN CFKBDS2007) is almost identical to that of the model tested in the laboratory. An abrupt change in $\mathrm{CO}_{2}$ and $\mathrm{CH}_{4}$ mole fraction during a switch between two dry gases follows the curves shown in Fig. 4 for "dry to dry" transitions (blue curve). We found that the response depends non-linearly on the magnitude of the change in $\mathrm{CO}_{2}$ or $\mathrm{CH}_{4}$ mole fraction, so we report ranges here. After an abrupt switch between two dry gases, the measurements for $\mathrm{CO}_{2}$ and $\mathrm{CH}_{4}$ reach $95 \%$ of their final value within 6$10 \mathrm{~s}$ and $99 \%$ within $11-19 \mathrm{~s}$. We conclude that the response time is likely not only a function of the flush time for the cell and related plumbing, but is probably also a function of the internal software of the instrument. This issue will be investigated further in the future.

\subsubsection{Short-term precision}

The short-term precision of each analyzer, indicated by the value of one standard deviation $(1 \sigma)$ of measurements of dry gas from a reference tank at the reported frequency, typically $\sim 0.5 \mathrm{~Hz}$, is indicated in Table 1 , both for laboratory and flight conditions. Pressure noise in the analyzer cavity due to aircraft motion is the cause of the significantly larger noise in the flight measurements. It should be noted that the values given in Table 1 are for flight at low altitudes (500-2000 m) with presumably higher turbulence. At high cruising altitudes, the short-term precision is significantly improved, indicating that the cavity pressure noise is 

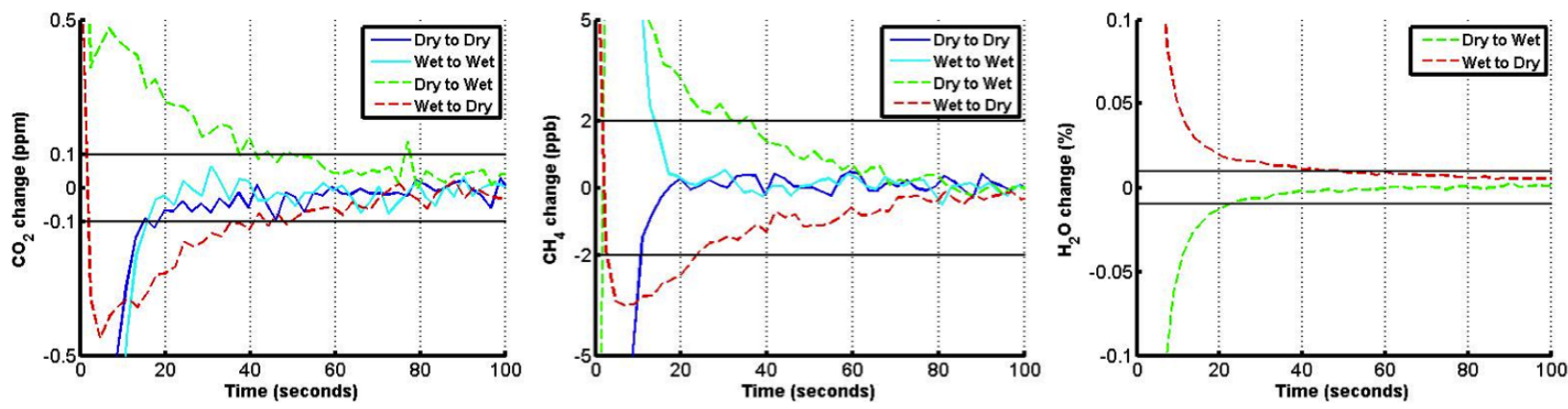

Fig. 4. Transition times between different standard gases for $\mathrm{CO}_{2}$ (left), $\mathrm{CH}_{4}$ (center), and water vapor (right), from a laboratory test, with parameters as they are at ACG. CO transition times were too short to be measurable within the instrument noise and are not shown. The WMO-recommended compatibility of measurements for $\mathrm{CO}_{2}$ and for $\mathrm{CH}_{4}$ is shown in solid black lines at $0.1 \mathrm{ppm}$ and $2 \mathrm{ppb}$, respectively. The solid black lines on the right panel indicate $0.01 \%$, or $100 \mathrm{ppm}_{2} \mathrm{O}$.
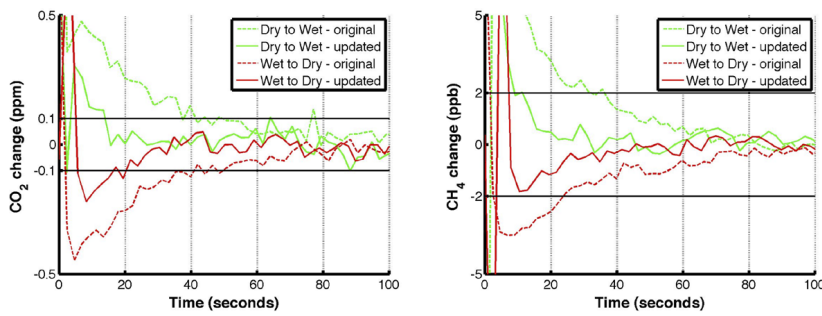

Fig. 5. Transition times from wet to dry gas (red) and from dry to wet (green) before (dashed lines) and after (solid lines) the analyzer software parameter change that controls the baseline response time. $\mathrm{CO}_{2}$ is shown in the left panel and $\mathrm{CH}_{4}$ on the right. The WMO-recommended compatibility of measurements is shown in solid black lines: $0.1 \mathrm{ppm}$ for $\mathrm{CO}_{2}$ and $2 \mathrm{ppb}$ for $\mathrm{CH}_{4}$.

not caused by high-frequency vibration of the aircraft propellers, but rather aircraft motion due to atmospheric turbulence in flight. During the 2012 season, a new proportional valve for controlling flow at the measurement cavity inlet was installed in CFKBDS2007, replacing the original valve. This valve (Clippard part no. EV-PM-10-6025-V) was chosen by Picarro to reduce the pressure noise in the cavity during flight. Flights with the new valve show significantly less cavity pressure noise during turbulent flight conditions (the standard deviation of 2.2-s pressure measurements improved from $0.4 \mathrm{hPa}$ to $0.08 \mathrm{hPa}$ ), and consequently the shortterm precision of the analyzer is dramatically improved, from $0.1 \mathrm{ppm}$ to $0.04 \mathrm{ppm}$ for $\mathrm{CO}_{2}$ and from $1 \mathrm{ppb}$ to $0.3 \mathrm{ppb}$ for $\mathrm{CH}_{4}$ (Table 1). The precision of the $\mathrm{CO}$ measurement in the G2401 series analyzer is not reduced by flight conditions or the introduction of a new proportional valve and remains the same throughout.

\subsubsection{Calibrations: long-term stability and in situ corrections}

The analyzers were calibrated in the laboratory each year prior to and after each season's deployment, with a series of four or five standard reference tanks. Reference
Table 1. Typical short-term precision of Picarro CRDS analyzers at the fastest measurement frequency $(\sim 0.5 \mathrm{~Hz})$. Flight condition values occur during turbulent portions of flights (i.e., low altitudes and/or altitude changes).

\begin{tabular}{lllll}
\hline Species & $\begin{array}{l}\text { CFADS08 } \\
(2009)\end{array}$ & $\begin{array}{l}\text { CFADS09 } \\
(2010)\end{array}$ & $\begin{array}{l}\text { CFKBDS2007 } \\
(2011)\end{array}$ & $\begin{array}{l}\text { CFKBDS2007 } \\
\left(2012^{*}\right)\end{array}$ \\
\hline $\mathrm{CO}_{2}$ (laboratory) & $0.05 \mathrm{ppm}$ & $0.05 \mathrm{ppm}$ & $0.03 \mathrm{ppm}$ & $0.03 \mathrm{ppm}$ \\
$\mathrm{CO}_{2}$ (flight) & $0.2 \mathrm{ppm}$ & $0.2 \mathrm{ppm}$ & $0.1 \mathrm{ppm}$ & $0.04 \mathrm{ppm}$ \\
$\mathrm{CH}_{4}$ (laboratory) & $0.4 \mathrm{ppb}$ & $0.4 \mathrm{ppb}$ & $0.2 \mathrm{ppb}$ & $0.2 \mathrm{ppb}$ \\
$\mathrm{CH}_{4}$ (flight) & $2 \mathrm{ppb}$ & $2 \mathrm{ppb}$ & $1 \mathrm{ppb}$ & $0.3 \mathrm{ppb}$ \\
$\mathrm{CO}$ (laboratory) & n/a & n/a & $4 \mathrm{ppb}$ & $4 \mathrm{ppb}$ \\
$\mathrm{CO}$ (flight) & n/a & n/a & $4 \mathrm{ppb}$ & $4 \mathrm{ppb}$ \\
\hline
\end{tabular}

* These data are for flights after the installation of a new inlet proportional valve.

tanks are calibrated on the World Meteorological Organization (WMO) scales $\left(\mathrm{CO}_{2} \mathrm{X} 2007\right.$, Zhao and Tans, 2006; $\mathrm{CO}$ X2004, and $\mathrm{CH}_{4} \mathrm{X} 2004$, Dlugokencky et al., 2005) at NOAA/ESRL. Drift in each analyzer between laboratory calibrations in March and December of the same year was found to be $\leq 0.05 \mathrm{ppm} \mathrm{CO}_{2},<2 \mathrm{ppb} \mathrm{CH}_{4}$, and $<3 \mathrm{ppb}$ for $\mathrm{CO}$ for the ambient range of mole fractions. Similar results have been shown for $\mathrm{CO}_{2}$ in other Picarro CRDS analyzers (Richardson et al., 2012). Flight measurements for all three species are initially corrected using this linear calibration prior to analysis of the on-board standards.

NOAA-calibrated reference tanks are deployed aboard the aircraft and sampled periodically during flight, with the analyzer typically sampling a single tank every $30 \mathrm{~min}$ for $3 \mathrm{~min}$, alternating between three different tanks for different calibration cycles. One set of three tanks was used for the entire 2009 and 2010 seasons, with a new set of three tanks deployed for the entire 2011 and 2012 seasons (Table 2). For two periods, only two tanks were used on-board. At the initial deployment in April 2009, a third tank was unavailable and was installed later in the season (July 2009). In April 2010, one tank was accidently left with a loose downstream connector during flight and lost pressure; it was replaced on 18 August 2010. When the 2009-2010 season tanks were returned to NOAA/ESRL, they were recalibrated to quantify 
Table 2. Standard natural air reference tanks deployed for in situ calibration of the CRDS GHG analyzer, with their calibrated mole fraction values. Tanks were calibrated at NOAA/ESRL prior to deployment. Unless a specific date is indicated, the tank was in use for the entire season.

\begin{tabular}{|c|c|c|c|c|c|}
\hline Tank \# & $\begin{array}{l}\text { Type/ } \\
\text { Volume (L) }\end{array}$ & In use dates & $\begin{array}{l}\mathrm{CO}_{2} \text { value } \\
(\mathrm{ppm})\end{array}$ & $\begin{array}{l}\mathrm{CH}_{4} \text { value } \\
(\mathrm{ppb})\end{array}$ & $\begin{array}{l}\mathrm{CO} \text { value } \\
(\mathrm{ppb})\end{array}$ \\
\hline CA01411 & N150/29.5 & 2009-2010 & 389.09 & 1851.9 & $\mathrm{n} / \mathrm{a}$ \\
\hline FA02798 & N30/5.9 & $\begin{array}{l}30 \text { Apr 2009- } \\
30 \text { Mar } 2010\end{array}$ & 419.09 & 1976.9 & $\mathrm{n} / \mathrm{a}$ \\
\hline FA03055 & N30/5.9 & $\begin{array}{l}13 \text { Jul 2009- } \\
30 \text { Nov } 2010\end{array}$ & 368.50 & 1744.3 & $\mathrm{n} / \mathrm{a}$ \\
\hline JA02336 & N60/10.8 & $\begin{array}{l}18 \text { Aug 2010- } \\
30 \text { Nov } 2010\end{array}$ & 459.79 & 2161.9 & $\mathrm{n} / \mathrm{a}$ \\
\hline CA02134 & AL150 & 2011-2012 & 396.11 & 1868.8 & 185.6 \\
\hline JB03049 & N60 & 2011-2012 & 365.48 & 1789.9 & 146.6 \\
\hline FA02798 & N30 & 2011-2012 & 434.85 & 2168.4 & 259.2 \\
\hline
\end{tabular}

any degradation or drift in the tanks; they were found to be within $0.05 \mathrm{ppm}$ for $\mathrm{CO}_{2}$ and $0.3 \mathrm{ppb}$ for $\mathrm{CH}_{4}$ of their predeployment calibration. The tanks deployed in March 2011 have not yet been returned for an intermediate calibration.

Analysis of in-flight tank measurements is described below for the 2011 season, for the model G2401-m analyzer. Unless specifically noted in the text, observations in previous seasons using the G1301-m series analyzers were similar. These statistics are reported for analyzer performance prior to the inlet proportional valve change mentioned in the previous section, which occurred too recently to compile performance statistics.

All reference tank measurements reported here are corrected using calibration factors determined from the laboratory calibration of the analyzer prior to that season's deployment. In-flight tank measurements, obtained by averaging the data from the last two minutes of a three-minute standard run, show little drift over the 8 flight hours, typically $<0.1 \mathrm{ppm}$ in $\mathrm{CO}_{2}, 1 \mathrm{ppb}$ in $\mathrm{CH}_{4}$, and $5 \mathrm{ppb}$ in $\mathrm{CO}$. However, there is some scatter in the residuals of the standard tank measurements. Residuals are the differences between the measurements of a tank (corrected using the pre-deployment laboratory calibration) and the assigned value of the tank (Fig. 6). One standard deviation of the residuals over the course of a single flight is $0.04 \mathrm{ppm} \mathrm{CO}_{2}, 0.3 \mathrm{ppb} \mathrm{CH}_{4}$, and $1.5 \mathrm{ppb} \mathrm{CO}$ on average. We note that the CRDS analyzer requires approximately 30 min after the cell reaches the set-point temperature and pressure to warm up. During this time, instrument precision and stability should be monitored, or measurements made during this time should be discarded. In Fig. 6 for $\mathrm{CO}_{2}$ (left panel), the first standard measurement is approximately $0.1 \mathrm{ppm}$ higher than subsequent measurements, which is an indication of this warm-up period.

To avoid introducing artificial noise into the sample data by correcting for shorter-term temporal changes in the standard measurements, the flight measurements are corrected only for the mean temporal drift that occurs in the standard measurements over the time of the entire flight. To perform this correction, a linear fit to the average of the residuals of all the available tanks with time is calculated (black dashed line in Fig. 6) and subtracted from the mole fraction of the sample stream. As a check on this technique, corrections to the measured mole fractions using other methods (such as using the instantaneous average of the tank residuals rather than a linear fit with time, or a using a time-varying first-order fit to the tank concentrations) are compared with the chosen method to ensure that the chosen correction technique is appropriate. If the final calibrated mole fractions are dependent on the technique choice by an amount greater than our target

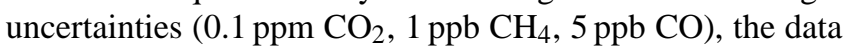
will be examined more thoroughly and a different calibration method could be used; this has not occurred so far on ACG flights.

In addition to their low variability within each flight, tank measurements on board the aircraft show little overall drift throughout each season. Because the same tanks are used throughout the season, we can quantify the drift of the measurement of individual tanks over the entire season. The 1- $\sigma$ variability of one flight tank measurement over the season is similar to that seen over the course of one flight $(0.04 \mathrm{ppm}$ $\mathrm{CO}_{2}, 1$ ppb CH 4 , and $1 \mathrm{ppb} \mathrm{CO}$ ) (Fig. 7). In 2011, the G2401$\mathrm{m}$ analyzer's $\mathrm{CH}_{4}$ calibration drifted upwards by approximately $2 \mathrm{ppb}$; the other two tanks showed the same trend. Post-deployment instrument calibration in the laboratory in January 2012 showed only a $1.4 \mathrm{ppb}$ change from the initial calibration in March 2011. If it were linear over time, the drift during the 7 months of the 2011 season should only have been approximately $1 \mathrm{ppb}$, rather than 2 . We do not suspect degradation of the reference tanks themselves, because all three tanks show the same trends. This will be confirmed when the tanks are returned to the laboratory for post-deployment calibration. Based on this information, we recommend that, for measurements of $\mathrm{CO}_{2}, \mathrm{CH}_{4}$ and $\mathrm{CO}$ using 1000 or 2000-series Picarro CRDS analyzers in the absence of in situ standards, a calibration should be performed at least every 6 months, depending on the specific analyzer and the uncertainty required for the measurement - annual calibrations of our analyzer may be sufficient to satisfy the 2 ppb WMO-recommended compatibility of measurements for $\mathrm{CH}_{4} \cdot \mathrm{CO}_{2}$ shows a slight drift of approximately $0.15 \mathrm{ppm}$ over the season (with no measurable drift in the laboratory calibrations). $\mathrm{CO}$ was stable, showing no long-term drift. In 2009 and 2010, the G1301-m analyzers deployed at the site showed no measurable drift in either $\mathrm{CH}_{4}$ or $\mathrm{CO}_{2}$; we conclude that this type of drift is analyzer-specific, and that periodic calibrations are necessary to track long-term analyzer drift.

The measured values of the standard tanks shown in Fig. 7 have also been examined as functions of aircraft cabin temperature and pressure, and altitude. No correlation has been found with any of these variables (shown for $\mathrm{CO}_{2}$ in Fig. 8, with similar results for both $\mathrm{CH}_{4}$ and $\mathrm{CO}$, and for the 2009 and 2010 seasons, not shown). 

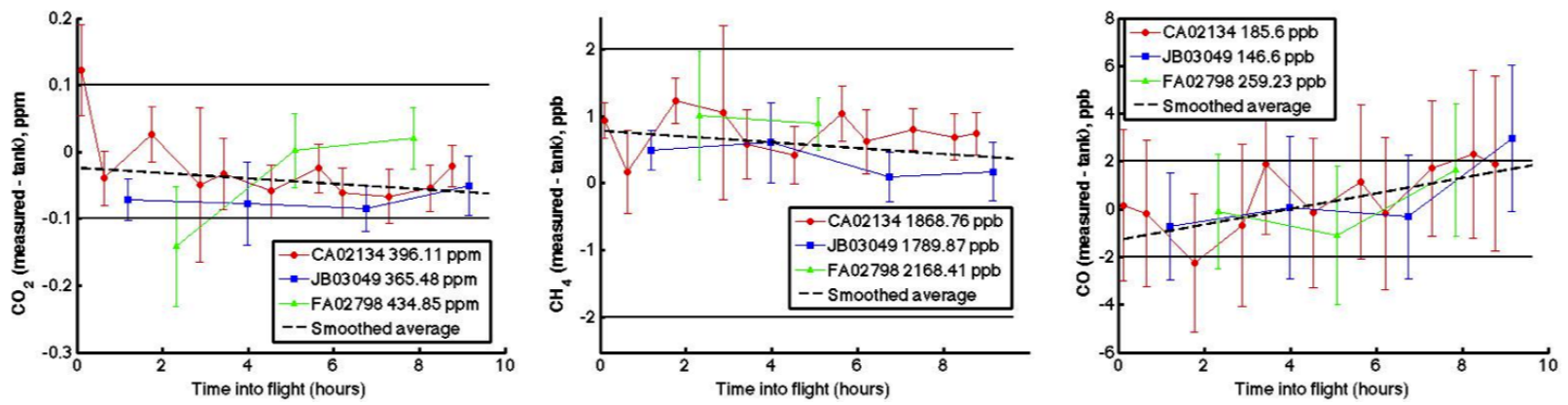

Fig. 6. Residuals of reference gas measurements for $\mathrm{CO}_{2}$ (left), $\mathrm{CH}_{4}$ (middle), and $\mathrm{CO}$ (right), during a flight on 4 April 2011. Different colors represent the different tanks, while the dashed black line is a linear fit with time to all the residuals. The dashed line is used to correct the sample mole fractions. Error bars are the standard deviation $(1 \mathrm{~s})$ of the $0.5-\mathrm{Hz}$ measurements of the standard gas during the $2-\mathrm{min}$ averaging time. Solid black lines represent the WMO compatibility goals.
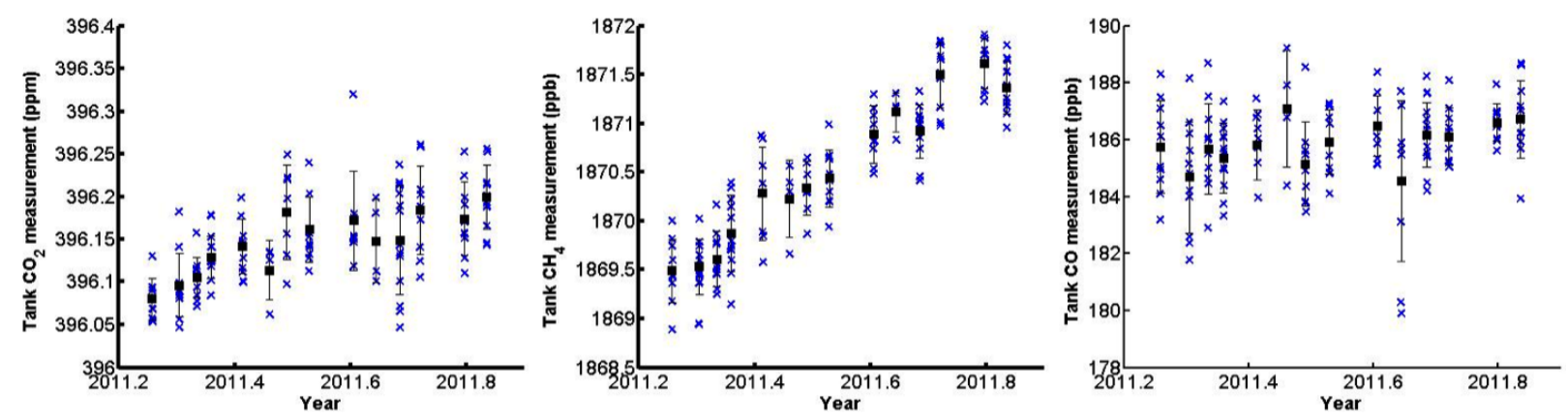

Fig. 7. Measurement of a reference gas tank on the aircraft during flight throughout the 2011 season for $\mathrm{CO}_{2}$ (left panel), $\mathrm{CH}_{4}$ (middle), and $\mathrm{CO}$ (right). Blue " $\mathrm{x}$ " symbols are the mean tank measurement during a single 3-min run; black squares are the average value during a single flight; error bars represent the standard deviation $(1 \sigma)$ around that average.

\subsubsection{Water vapor correction}

An important advantage to the CRDS units used for the ACG flights is that dry air mole fractions of $\mathrm{CO}_{2}, \mathrm{CH}_{4}$, and $\mathrm{CO}$ can be calculated using empirical water vapor corrections that compensate for dilution, pressure broadening, and line interferences due to water vapor (Richardson et al., 2012; Rella et al., 2012; Chen et al., 2012a; Nara et al., 2012). Laboratory tests were performed on each unit prior to and after deployment in the field to determine and assess the stability of these empirical water vapor corrections. Empirical water vapor correction tests were performed using two different methods to add water vapor to dry standard gases from tanks. One method used standard gas flowing through either a wetted stainless steel filter housing or through the same filter housing filled with silica gel that had been wetted with acidified ( $\mathrm{pH} \sim 5$ ), distilled water. Using wetted silica gel to deliver the water vapor to the gas stream resulted in a smoother water vapor transition across a range of about $2.5 \%$ to fully dry. The second method similarly wetted the standard gas using a hydrophobic membrane (Celgard, "MicroModule") loaded with a small amount $(\sim 2 \mathrm{~mL})$ of acidified, distilled water. No significant drifts in these water vapor correction functions have been observed. Methodology for performing these water vapor tests is described in detail elsewhere for $\mathrm{CO}_{2}$ and $\mathrm{CH}_{4}$ (Chen et al., 2010; Winderlich et al., 2010; Rella et al., 2012), and for CO (Chen et al., 2012a).

The water vapor correction for $\mathrm{CO}_{2}$ and $\mathrm{CH}_{4}$ takes the form of

$$
\frac{X_{G, \text { wet }}}{X_{G, \text { dry }}}=1+a \times \mathrm{H}_{2} \mathrm{O}_{\text {reported }}+b \times \mathrm{H}_{2} \mathrm{O}_{\text {reported }}^{2}
$$

where $X_{G}$ is either $\mathrm{CO}_{2}$ or $\mathrm{CH}_{4}, \mathrm{H}_{2} \mathrm{O}_{\text {reported }}$ is the variable "h2o_reported" in the Picarro output file (this is an uncalibrated water vapor measurement), and the coefficients $a$ and $b$ are determined in laboratory testing. We found the water vapor corrections did not change by more than $0.1 \mathrm{ppm}$ for $\mathrm{CO}_{2}$ or $1 \mathrm{ppb}$ for $\mathrm{CH}_{4}$ at the highest $\mathrm{H}_{2} \mathrm{O}$ values used in laboratory tests, approximately $2.5 \%$. In typical flights, $\mathrm{H}_{2} \mathrm{O}$ values were lower than this level, usually below $1.5 \%$.

The water vapor correction for $\mathrm{CO}$ takes a different form, because there is significant absorption interference from $\mathrm{CO}_{2}$ and water with the $\mathrm{CO}$ absorption line (details in Chen et al., 2012a). For this dataset the correction used is

$$
\begin{aligned}
& \mathrm{CO}_{\text {corrected }}= \\
& \frac{\mathrm{CO}_{\text {wet }}-\left(A \times \mathrm{H}_{2} \mathrm{O}_{\mathrm{pct}}+B \times \mathrm{H}_{2} \mathrm{O}_{\mathrm{pct}}^{2}+C \times \mathrm{H}_{2} \mathrm{O}_{\mathrm{pct}}^{3}+D \times \mathrm{H}_{2} \mathrm{O}_{\mathrm{pct}}^{4}\right)}{1+a^{\prime} \times \mathrm{H}_{2} \mathrm{O}_{\mathrm{pct}}+b^{\prime} \times \mathrm{H}_{2} \mathrm{O}_{\mathrm{pct}}^{2}},
\end{aligned}
$$


where $\mathrm{CO}_{\text {wet }}=$ peak84raw*0.427 (C. Rella, Picarro, personal communication, 2011), and "peak84raw" is the reported value for the raw $\mathrm{CO}$ measurement in the analyzer data stream. The parameters $A, B, C, D, a^{\prime}$, and $b^{\prime}$ are empirically determined from laboratory water experiments.

The water vapor variable reported by Picarro ("h2o_pct") is determined from the water vapor absorbance line that overlaps with the $\mathrm{CO}$ absorbance line used in the G2401, and is different from the water vapor measurement used for the $\mathrm{CO}_{2}$ and $\mathrm{CH}_{4}$ correction ("h2o_reported"). Incidentally, the actual water vapor measurement that Picarro reports is the variable "H2O" and is related to "h2o_reported" (Winderlich et al., 2010). The uncertainty of the CO water vapor correction is within 2 ppb up to $4 \%$ water vapor (Chen et al., 2012a). This uncertainty in the $\mathrm{CO}$ correction is one of the main contributors in the uncertainty of continuous $\mathrm{CO}$ measurements at ACG. Although it is smaller than the short-term precision $(4 \mathrm{ppb})$ of the same analyzer, it may introduce a bias in the result rather than random noise.

\subsection{Flask packages}

Programmable Flask Packages (PFPs) are used to collect discrete air samples on the C-130 flights. These airsampling devices are used routinely on aircraft as part of the NOAA/ESRL Global Monitoring Division's Carbon Cycle and Greenhouse Gases network (Sweeney et al., 2013, and http://www.esrl.noaa.gov/gmd/ccgg/aircraft/ index.html). The PFP is composed of twelve $0.7 \mathrm{~L}$ borosilicate glass flasks with glass valves sealed with Teflon O-rings at each end, a stainless steel manifold, and a data logging and control system. The $7.5 \mathrm{~cm}$ diameter cylindrical flasks are stacked in two rows of six. The flexible manifold connects all of the flasks in parallel on the inlet side of the flasks. The data logger records actual sample flush volumes and fill pressures during sampling, along with system status, GPS position, ambient (outside the aircraft) temperature, and relative humidity. One or two PFPs are sampled on each flight (12 or 24 flasks). A rack-mounted Programmable Compressor Package (PCP) that contains two air pumps (KNFNeuberger MPU1906-N828-9.06 and PU1721-N811-3.05) with aluminum heads and Viton diaphragms plumbed in series is used to flush and pressurize the flasks.

Samples collected in PFPs are analyzed at NOAA/ESRL for $\mathrm{CO}_{2}, \mathrm{CH}_{4}, \mathrm{H}_{2}, \mathrm{SF}_{6}, \mathrm{CO}$, and $\mathrm{N}_{2} \mathrm{O}$ on either of two nearly identical automated analytical systems. These systems consist of a custom-made gas inlet system, gas-specific analyzers, and system-control software; they use a series of stream selection valves to select an air sample or standard gas and pass it through a trap for drying maintained at $\sim-80^{\circ} \mathrm{C}$, before sending the sample to an analyzer. All measurements are reported as dry air mole fractions relative to standard scales maintained at NOAA/ESRL (Novelli, 2003; Dlugokencky et al., 2005; Hall et al., 2007; Novelli et al., 1991; Zhao and Tans, 2006).
The same flask samples are also analyzed for a suite of halocarbons and hydrocarbons, as well as stable isotopes of $\mathrm{CO}_{2}$ (both ${ }^{13} \mathrm{C}$ and ${ }^{18} \mathrm{O}$, at INSTAAR, University of Colorado) using methods documented online (http://www.esrl. noaa.gov/gmd/ccgg/aircraft/index.html), and by Montzka et al. (1993) and Vaughn et al. (2004). Uncertainties for species measured in flasks are documented in the references above.

\subsection{Auxiliary measurements}

\subsubsection{Temperature and relative humidity}

A Vaisala HMP-50 temperature and relative humidity probe is mounted on the exterior of the inlet plate. It has been fitted with a custom housing that allows airflow to reach the sensor without allowing solar radiation to affect measurements. The sensor was calibrated by the manufacturer prior to purchase to a typical uncertainty of $\pm 3 \%$ of relative humidity and $0.6^{\circ} \mathrm{C}$ for temperature.

\subsubsection{Global positioning system (GPS) and timing}

GPS location and time from the aircraft navigation system are logged both by the CR1000 data logger (see Sect. 2.4.3) and the flask system at 10-s intervals during flight. The data are interpolated onto a 1-sec time scale. Data from the CRDS analyzer are corrected for the lag time in the inlet system; the lag time is measured on the ground and corrected based on outside air pressure.

\subsubsection{Data collection and system control}

Deploying a trace gas sampling and measurement system without a scientist on-board requires having a robust method for controlling and recording system parameters and collecting data post-flight. An additional unit in the instrument rack at ACG is a control box that contains a Campbell Scientific CR1000 data logger, the MPV, pressure sensors and the plumbing connections. The data logger plays a central role in the system and serves a variety of functions: (1) it records the outputs of the CRDS analyzer, ozone analyzer, temperature and humidity sensor, and GPS system via serial communications; (2) controls the MPV to deliver the sample and reference gases to the CRDS analyzer; (3) triggers the PFP package to sample at pre-programmed time intervals if no operator is available to trigger them manually; and (4) logs the output of ancillary sensors that are needed to monitor the function of the overall system. The ancillary sensors include several pressure sensors to measure cabin pressure, inlet line pressure, and the analyzer inlet pressure. The inlet line pressure, once it is corrected for the pressure drop due to flow through the inlet line (which is also dependent on the external pressure), is effectively the ambient pressure outside the aircraft. The analyzer inlet pressure is either equal to the inlet line pressure or it is equal to the delivery pressure of the standards, depending on the MPV position. This pressure 

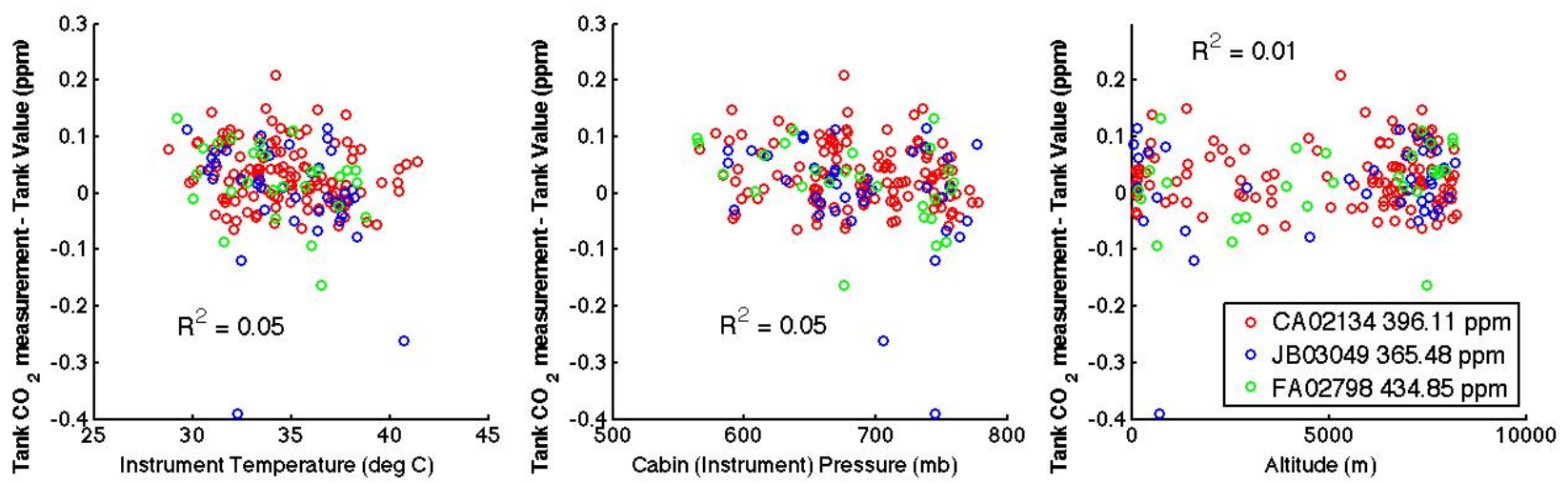

Fig. 8. Measurement of a reference gas tank in 2011, relative to the calibrated tank value, as a function of three environmental variables: instrument temperature (left), cabin pressure (middle), and aircraft altitude (right). Data from all three on-board tanks are shown in different colors, along with the correlation coefficient $\left(R^{2}\right)$ and equation of a linear fit for each. The measured value is determined using the predeployment laboratory calibration only.

measurement is needed to determine if the calibration tank regulators require adjustment.

Prior to the flight, a technician installs the flask packages, powers up the system, inserts a flash card into the CR1000 card reader, and then flushes gas through the standard tank regulators. A regulator-flushing protocol that did not require a technician was designed and implemented in 2009, but the long time interval between flights and the fact that a technician was available made it more efficient to purge the regulators manually. Once powered, the continuous system requires no operator. Upon landing, the operator removes the CR1000 flash card, downloads data from the CRDS analyzer via a USB flash drive, and ships the samples and data cards back to NOAA/ESRL in Boulder, Colorado.

\subsection{Comparison of CRDS and flask measurements}

The flask air samples are collected through a separate inlet line and measured by analyzers at NOAA/ESRL, which are calibrated with a set of reference gas standards on the same scale as the in situ system's reference gas standards for CO, $\mathrm{CO}_{2}$ and $\mathrm{CH}_{4}$. Thus, the flask air samples are independent of the continuous measurements and provide a useful reference to other NOAA global sites. An ongoing comparison thus provides a realistic measure of the overall uncertainty of the entire measurement process. Flask sample measurements are compared with the continuous in situ measurements by averaging the continuous data over the flushing and filling time of the flasks, using a weighting function similar to that described in Chen et al. (2012b). The flask system records the times (from the GPS antenna) at which the flask sample is triggered and at which it is complete, so that the timing between the flasks and the continuous systems is coordinated, as long as the difference in line lag time is considered. None of the $\mathrm{CO}_{2}$ data collected with the inlets that depleted $\mathrm{CO}_{2}$ in the sample in early 2011 (Sect. 2.1) are included in this comparison, but it is important to note that the inlet problem was quickly discovered because of the observed differences between flask and in situ measurements.

Histograms of the flight differences between continuous (CRDS) and flask measurements of $\mathrm{CO}_{2}$ (Fig. 9), $\mathrm{CH}_{4}$ (Fig. 10) and $\mathrm{CO}$ (Fig. 11) show little bias but significant scatter around the mean. Some of the scatter can be attributed to uncertainties in timing; because there is no pressure measurement in the flasks, the flask flushing and filling sequence is modeled based on laboratory measurements (Neff, 2013). Some of the scatter, however, cannot be attributed to timing issues. For example, when flasks filled during periods of high variability are omitted from the calculation, the standard deviation of offsets is still relatively large compared to the mean. In 2011, the offsets (in situ - flask) for $\mathrm{CO}_{2}$ (Fig. 9c) are -0.16 (mean) $\pm 0.42(1-\sigma) \mathrm{ppm}$. Considering only flasks filled during periods of low atmospheric variability (1- $\sigma$ variability in the continuous analyzer over the flask flush and fill time $<0.2 \mathrm{ppm}$ ), the offsets are -0.20 (mean) \pm 0.27 (1$\sigma)$ ppm for $\mathrm{CO}_{2}$. For $\mathrm{CH}_{4}$, the offsets in 2011 change from $0.4 \pm 1.8 \mathrm{ppb}$ to $0.4 \pm 1.3 \mathrm{ppb}$ when considering flasks filled during variability $<3 \mathrm{ppb}$, and for $\mathrm{CO}$ there is no measurable improvement (from $-0.6 \pm 2.8 \mathrm{ppb}$ to $-0.6 \pm 2.6$ ) when considering variability $<5 \mathrm{ppb}$.

The absolute bias (mean) of the $\mathrm{CO}_{2}, \mathrm{CH}_{4}$, and $\mathrm{CO}$ in situ to flask comparisons is smaller than the variability $(1-\sigma$ standard deviation) but larger than the standard error $(\sigma / \sqrt{N})$ (in all cases except for $\mathrm{CH}_{4}$ in 2009), indicating that the bias, although smaller than our target uncertainty in most cases, is statistically significant. The $\mathrm{CO}_{2}$ median offsets in 2010 and 2011 ( -0.08 and -0.09 , Fig. $9 b$ and c) and the $\mathrm{CH}_{4}$ median offsets in all three years $(-0.1,0.5$, and $0.5 \mathrm{ppb}$, Fig. 10a-c) meet the WMO compatibility goals (i.e., $0.1 \mathrm{ppm}$ for $\mathrm{CO}_{2}$ and $2 \mathrm{ppb}$ for $\mathrm{CH}_{4}$ ). The means for $\mathrm{CO}_{2}$ reflect several flask outliers, where the flasks are biased high. High $\mathrm{CO}_{2}$ flask measurements have been recently observed in flask to 


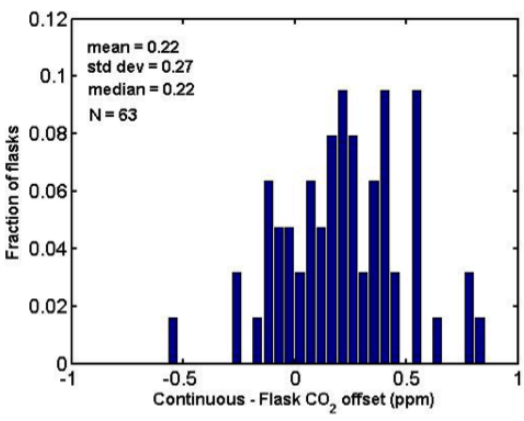

(a)

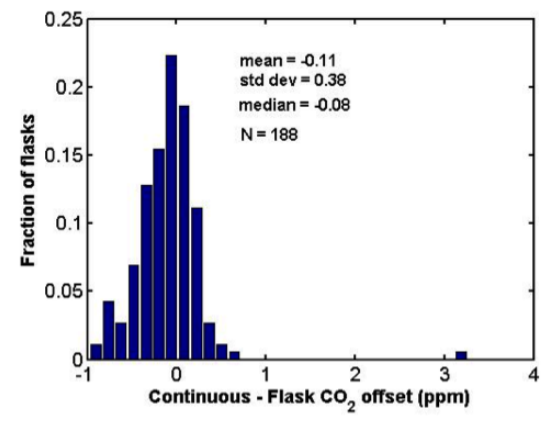

(b)

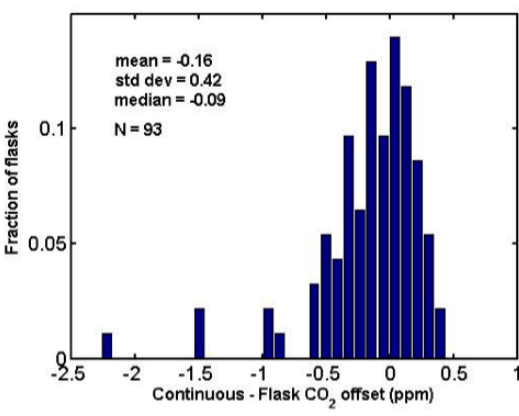

(c)

Fig. 9. Differences between continuous (CRDS) $\mathrm{CO}_{2}$ measurements and flask $\mathrm{CO}_{2}$ measurements during flights over Alaska on the USCG C-130 for three seasons: (a) 2009, (b) 2010, and (c) 2011. Negative offsets occur when the flask-measured mole fraction is higher than the continuous measurement. The mean for each season, $1-\sigma$ standard deviation, and number of flasks for comparison are indicated on each figure.

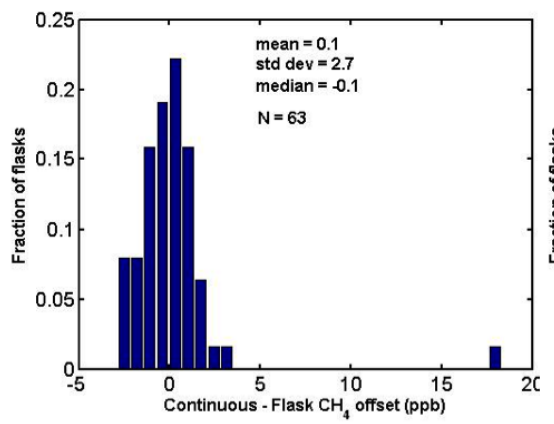

(a)

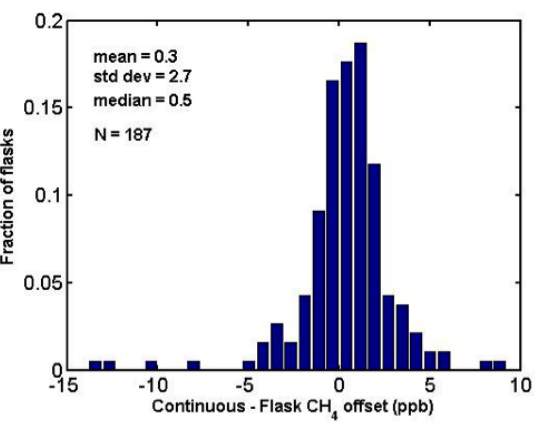

(b)

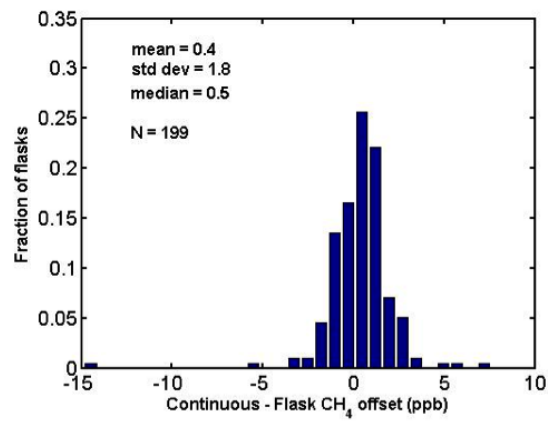

(c)

Fig. 10. Differences between continuous (CRDS) $\mathrm{CH}_{4}$ measurements and flask $\mathrm{CH} 4$ measurements during flights over Alaska on the USCG C-130 for three seasons: (a) 2009, (b) 2010, and (c) 2011. The mean for each season, 1- $\sigma$ standard deviation, and number of flasks for comparison are indicated on each figure.

in situ comparisons at NOAA ground sites as well, and seem to have become more prevalent since 2011 (Andrews et al., 2013). Laboratory tests are currently underway to determine the cause of these high $\mathrm{CO}_{2}$ flask anomalies, which is currently unknown. $\mathrm{CO}$ measurements show a mean bias smaller than the WMO compatibility goal (2 ppb) in 2011, and the offsets between the CRDS measurements and the flask measurements have been shown to have no dependence on day of year, water vapor, ambient pressure, $\mathrm{CO}_{2}, \mathrm{CH}_{4}$, or $\mathrm{CO}$ (Chen et al., 2012a).

In 2009, although the scatter of the offsets is small, the median $\mathrm{CO}_{2}$ offset is significantly greater than WMO compatibility goal $(+0.22 \mathrm{ppm})$. Subsequent re-analysis of the continuous data using only a laboratory calibration from December 2009 (i.e., not using the correction of the on-board tanks) reduces the bias to $0.04 \mathrm{ppm}$. Although we have no reason to reject the in situ calibrations outright, this fact does suggest the possibility of a problem in the standard delivery (the tanks were calibrated at NOAA post-mission and were within $0.1 \mathrm{ppm}$ of $\mathrm{CO}_{2}$ from their initial calibration, so tank drift is not likely to be a factor). It is possible that the reference tank regulators were not adequately flushed. The two tanks that were not run as frequently (high and low targets that ran once every $3 \mathrm{~h}$ ) showed clear evidence of lack of flushing, with very low measured values; they were not used in the calibration at all in 2009 for this reason. The ambient-level tank, which was run every $30 \mathrm{~min}$, was the only tank used for in situ calibration and may also have been inadequately flushed. Inadequate flushing would lead to low measurements of the standard tank, and subsequently higher values of the sample measurement, consistent with the positive offset relative to flasks. It was during this 2009 season that, rather than being manually flushed by the on-board technician, the regulators underwent an automated flushing sequence in which the tanks ran more frequently at the start of the flight. In 2010, the on-board technician began to do a more rigorous flushing of the regulators by hand prior to departure, flushing the entire regulator volume at least three times, and results improved. Whatever the cause, the data from subsequent years do not show this bias in $\mathrm{CO}_{2}$. 


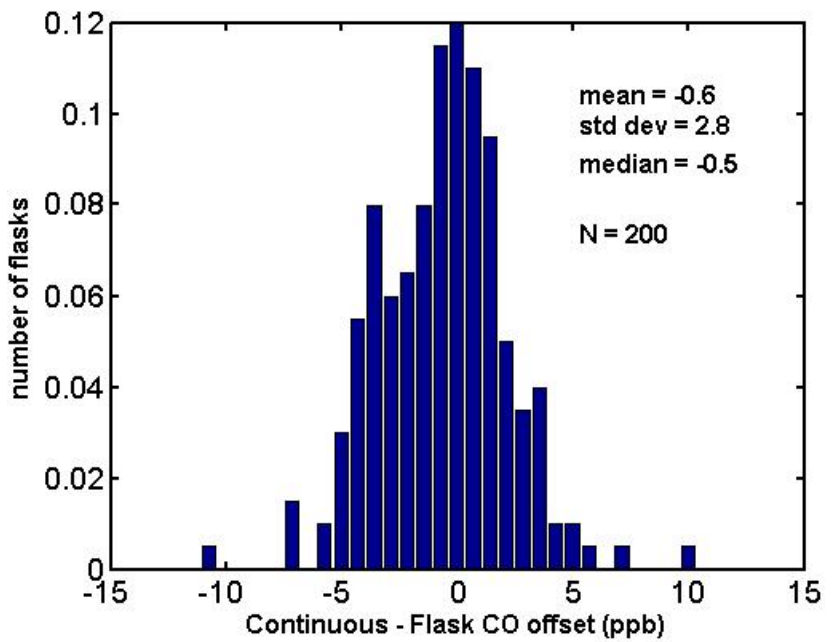

Fig. 11. Differences between continuous (CRDS) CO measurements and flask $\mathrm{CO}$ measurements during flights over Alaska on the USCG C-130 for 2011. The mean, $1-\sigma$ standard deviation, and number of flasks $(N)$ are indicated on the figure.

The in situ to flask comparison for $\mathrm{CO}_{2}$ for all years does not meet the WMO-recommended compatibility of measurements (mean of $0.1 \mathrm{ppm}$ for $\mathrm{CO}_{2}$ ) even when periods of high variability have been filtered out. In trying to understand the cause of this poor repeatability between continuous and flask measurements of $\mathrm{CO}_{2}$, it is important to consider Figs. 6, 7, and 8 , which demonstrate the stability of the standard measurements not only over a season but also for each flight (standard deviations for both under $0.04 \mathrm{ppm}$ in $\mathrm{CO}_{2}$ ). Separate water vapor correction tests suggest that in $1 \%$ water vapor there is an additional uncertainty due to possible drift in the correction of less than $0.1 \mathrm{ppm}$ (Rella et al., 2012). Taken together $(\sim 0.14 \mathrm{ppm}$ when summed in quadrature) these errors are significantly smaller than the observed repeatability suggesting that there are errors in gas handling upstream of the standard tank introduction or that there are errors in the flask measurements contributing to poor reproducibility.

To test the integrity of the in situ gas handling, thorough leak checks on all inlet lines are performed whenever possible (prior to each season at the minimum). Two additional tests are performed annually on the aircraft system: (1) a standard gas is run through a portion of the inlet line at ambient external pressure during flight (by utilizing a tee fitting for excess flow outside the aircraft); and (2) on the ground, a standard gas is run through the complete inlet line from the exterior of the aircraft. These tests are performed at least once per year to evaluate the effects of both low pressure and of any kind of contamination in the inlet line, and have proven valuable in confirming that the in situ analyzer stream has not been contaminated prior to entering the MPV.

Testing of the PFP sampling system is also routinely performed. Laboratory tests done with PFP flasks filled sequentially with a single tank and compared with single glass flasks (typically used in the NOAA ground network) show measurement offsets of $-0.09 \pm 0.05 \mathrm{ppm}$ for $\mathrm{CO}_{2}$ (http://www.esrl.noaa.gov/gmd/ccgg/aircraft/qc.html). Recent analysis of wet samples in the laboratory and comparisons with in situ $\mathrm{CO}_{2}$ measurement systems on towers (Andrews et al., 2013) suggest that the PFP flasks may have uncertainties as high as $1 \mathrm{ppm}$ for $\mathrm{CO}_{2}$ due to possible surfacewater interactions when sampling wet air (as is done on the $\mathrm{C}-130$ ) or due to residual water vapor in PFP flasks from insufficient drying prior to sampling. Unlike lower-pressure network flasks, the PFP flasks store air samples at $2700 \mathrm{hPa}$; effects of off-gassing from any surface area exposed to the sample will therefore be amplified. Tests of the PFP flasks and sampling system are on-going at NOAA and are targeted towards both resolving the discrepancy between the in situ and flask measurements and determining a more accurate uncertainty on the flask measurements of $\mathrm{CO}, \mathrm{CH}_{4}$, and $\mathrm{CO}_{2}$.

The higher than desired uncertainty for $\mathrm{CO}_{2}$ on both systems is a critical reminder that accurate GHG measurements must be validated whenever possible, and that frequent sampling of standards during flight may not be an adequate assessment of the true uncertainty of a system. When measurements are performed autonomously, especially when independent validation is not routine (e.g., flask vs. in situ comparisons are not possible), we recommend periodic confirmation of measurements by either independent validation or rigorous tests such as those described above.

\subsection{Water vapor measurement}

Not drying the sample stream to the CRDS allows us to measure ambient water vapor in addition to $\mathrm{CO}_{2}, \mathrm{CH}_{4}$ and $\mathrm{CO}$. Water vapor gradients are an important constraint on the boundary layer height, and the data can serve as an important way to evaluate vertical mixing in transport models. Although there is no specific advantage to measuring water vapor with CRDS compared with other sensors, here we show comparisons between the measurements of the CRDS instrument and the Vaisala HMP-50 relative humidity sensor deployed on the same aircraft. The water vapor measurement of the CRDS analyzers is based on a laboratory calibration done on a single instrument (Winderlich et al., 2010), reported at approximately $0.5 \mathrm{~Hz}$ in the 2000-series analyzers along with the three other species. We note that the response time of the $\mathrm{H}_{2} \mathrm{O}$ measurement when switching from a wet to a dry gas is approximately $40 \mathrm{sec}$ to arrive within $0.01 \%$ (or $100 \mathrm{ppm}$ ) of the final value in flight (Fig. 4, right panel, shows the same result from a laboratory experiment with the same model analyzer). Figure 12 (left panel) illustrates that, during an altitude ascent and descent (on 28 June 2011 over Galena), the CRDS water vapor measurements agree well and do not show significant lag due to this response time or due to the long inlet line. In the right panel of the same figure, the descending profile is compared to the $\mathrm{H}_{2} \mathrm{O}$ calculated using 

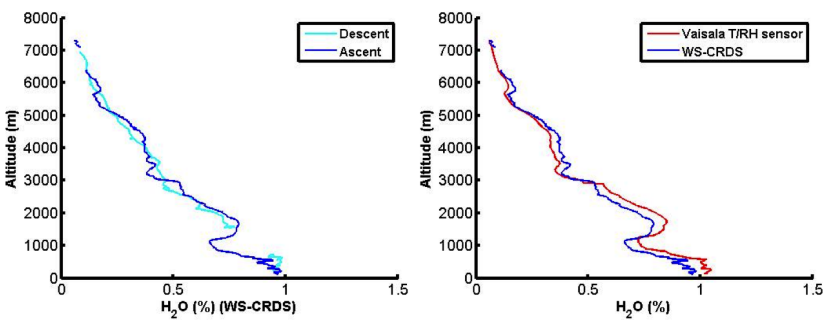

Fig. 12. Altitude profiles of water vapor $\left(\mathrm{H}_{2} \mathrm{O}\right)$ measurements over Galena on 28 June 2012. Left panel: ascent and descent measurements from the CRDS analyzer (data gaps exist during calibration periods). Right panel: ascent measurements from both CRDS (blue) and calculated from in situ temperature and RH measurements (red).

the Vaisala temperature and relative humidity measurements, along with the external ambient pressure measurement, and equations from Goff (1957) and Buck (1981). Vertical gradients in $\mathrm{H}_{2} \mathrm{O}$ are well resolved in both cases, although some difference in response time is apparent (the Vaisala probe has a response time that depends on various factors, including airspeed and the orientation of the protective shield).

Over the 2011 season, measurements from the CRDS analyzer and the T/RH sensor compare well considering the uncertainty in the Vaisala temperature and relative humidity measurements is reported to be $1 \%$ of the reading, with a high correlation $\left(R^{2}=0.99\right)$ and slope close to unity (Fig. 13). Further analysis, along with laboratory calibration, is required to evaluate the stability and the site-to-site comparability of the CRDS system for water vapor. However, the flight data show that the CRDS analyzer is capable of capturing gradients in $\mathrm{H}_{2} \mathrm{O}$ that can be used to determine boundary layer height.

\section{Results and conclusions}

The GHG measurement system designed to operate on the USCG C-130 aircraft in Alaska is simple and robust. We recognize some trade-offs are necessary and have chosen a simple system despite somewhat degraded response time (resulting from a slow change in baseline related to water vapor), leading to a loss of some measurements surrounding calibration cycles. The decisions made in favor of a simpler system, such as not drying the sample stream, do not increase the measurement error of the in situ data beyond the stated uncertainties, and allow for the measurement of water vapor. For the 2011 season, estimated uncertainties (of the native 2.5 -s measurements) are $0.15 \mathrm{ppm}, 1.4 \mathrm{ppb}$, and 5 ppb for $\mathrm{CO}_{2}, \mathrm{CH}_{4}$, and $\mathrm{CO}$ respectively, considering shortterm precision, calibration uncertainties and water vapor correction uncertainties. In 2009 and 2010, the uncertainties are slightly larger because of inferior short-term precision of the older analyzers: $0.23 \mathrm{ppm}\left(\mathrm{CO}_{2}\right)$ and $2.3 \mathrm{ppb}\left(\mathrm{CH}_{4}\right)$.

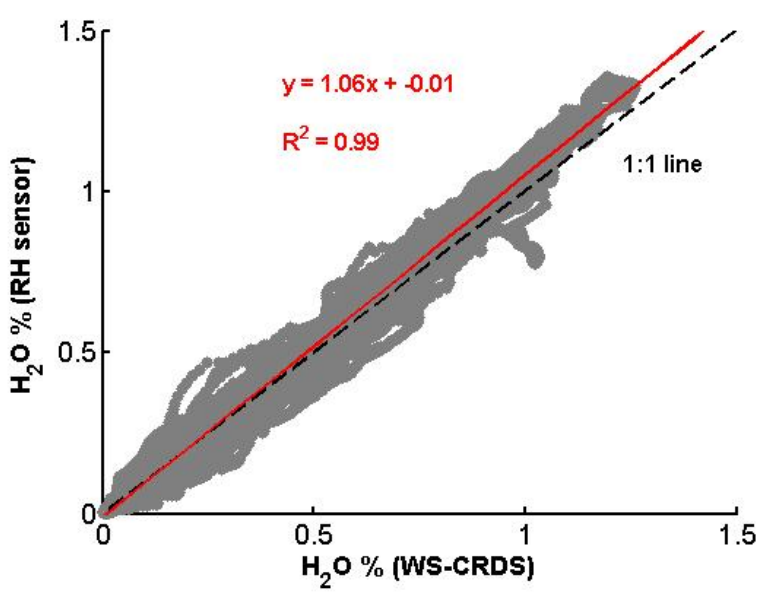

Fig. 13. Comparison of CRDS $\mathrm{H}_{2} \mathrm{O}$ with values calculated from the temperature and relative humidity sensor over the entire 2011 season. Red line shows the linear fit to the data, while the black dashed line indicates the $1: 1$ relationship.

Uncertainties are lower for measurements made in low turbulence (and therefore better short-term precision than the upper limit we have used in our uncertainty estimate), because the short-term precision contributes significantly to the total uncertainty. From 2012 onward, we expect lower uncertainties for $\mathrm{CO}_{2}$ and $\mathrm{CH}_{4}$ than 2011 because of the better pressure control of the analyzer cell after the installation of a new proportional valve (Sect. 2.2.3). These results do not suggest that variations in pressure or temperature affect the CRDS measurements in any way.

The large size of the aircraft used at this site allows for a relatively large payload, which has allowed NOAA to deploy flasks along with the CRDS system for measuring $\mathrm{CO}_{2}$, $\mathrm{CH}_{4}$, and $\mathrm{CO}$, thus giving a real assessment of the uncertainties for each. The C-130 payload capacity also allows for the deployment of three gas standard tanks for calibration of the CRDS analyzer, allowing us to evaluate the optimal in-flight calibration strategy. We have found that high frequency (every $30 \mathrm{~min}$ ) calibrations may not be necessary because of the high stability of the CRDS analyzer. For ACG flights, the same low measurement error could be achieved by running two reference tanks at a frequency that allows for at least two measurements of each tank during a single flight (to confirm repeatability), for example at the start and end of each flight. Deploying only a single tank would be acceptable but would make it more difficult to assess degradation in the tank itself as a cause of drift in the measurement.

In 2009, we found that a sampling problem (possibly inadequate regulator flushing) may have impacted the data quality and had better agreement with flask measurements when no in situ tank calibrations were used at all. These findings suggest that, when calibrations are run on an in situ remote system, extreme care must be taken in the gas handling for 
both the standards and the sample. In the case of our ACG deployments, it would have been possible to deploy our analysis system without standards given the low flight-to-flight variability of the laboratory calibration with respect to inflight measurements. However, we recommend that a target gas be used to track drift between flights if possible. It is worth noting that the most significant measurement problem encountered to date was the depletion of $\mathrm{CO}_{2}$ in the aluminum inlet line early in the 2011 season. This problem could not have been discovered based on in-flight calibrations and was revealed only by comparison with independent flask measurements. Periodic tests, as frequently as possible, of the entire system inlet are also recommended. Overall, three years of autonomous aircraft deployment of the CRDS system suggest that six-month deployments are possible without on-board calibrations, provided rigorous preand post-deployment laboratory tests are performed, including checking sample handling, water vapor testing, and quantifying drift from standards calibrated on the WMO scale. The expected uncertainty of such measurements without onboard calibrations (using the current ACG analyzer unit with a new proportional valve with better pressure control) is $0.13 \mathrm{ppm}$ for $\mathrm{CO}_{2}, 1.4 \mathrm{ppb}$ for $\mathrm{CH}_{4}$, and $5 \mathrm{ppb}$ for $\mathrm{CO}$, essentially the same as the estimated uncertainty of our 2011 measurements with on-board calibrations but without the new valve.

Data acquired at the Alaska Coast Guard site over three seasons have been shown to be of high quality and will be valuable for investigations of the Arctic and boreal carbon cycle. These repeated measurements from the same locations in different seasons and years are valuable for determining seasonal and long-term trends as well as inter-annual variability. Data from ACG are available from the corresponding author until they become available online at the NOAA Carbon Cycle server (http://www.esrl.noaa.gov/gmd/dv/data/).

Acknowledgements. We would like to acknowledge the valuable assistance of Jason Manthey, our current technician and operator in Kodiak, Alaska, our past technician, Margo Connolly, and the US Coast Guard Air Station Kodiak. We would also like to acknowledge the extensive help we have received from Doug Guenther, Jack Higgs, Paul Novelli, Pat Lang, Ed Dlugokencky, Duane Kitzis, Laura Patrick, Sam Oltmans, and Sara Crepinsek, all at NOAA/ESRL Global Monitoring Division. We thank Chris Rella at Picarro for valuable assistance with various aspects of the CRDS gas analyzers, and the CARVE Science Team for assistance and advice. This effort was funded by NOAA through the North American Carbon Program.

Edited by: O. Tarasova

\section{References}

Andrews, A. E., Kofler, J. D., Trudeau, M. E., Williams, J. C., Neff, D. H., Masarie, K. A., Chao, D. Y., Kitzis, D. R., Novelli, P. C., Zhao, C. L., Dlugokencky, E. J., Lang, P. M., Crotwell, M. J., Fischer, M. L., Parker, M. J., Lee, J. T., Baumann, D. D., Desai, A. R., Stanier, C. O., de Wekker, S. F. J., Wolfe, D. E., Munger, J. W., and Tans, P. P.: $\mathrm{CO}_{2}, \mathrm{CO}$ and $\mathrm{CH}_{4}$ measurements from the NOAA Earth System Research Laboratory's Tall Tower Greenhouse Gas Observing Network: instrumentation, uncertainty analysis and recommendations for future highaccuracy greenhouse gas monitoring efforts, Atmos. Meas. Tech. Discuss., 6, 1461-1553, doi:10.5194/amtd-6-1461-2013, 2013.

Biraud, S. C., Torn, M. S., Smith, J. R., Sweeney, C., Riley, W. J., and Tans, P. P.: A multi-year record of airborne $\mathrm{CO}_{2}$ observations in the US Southern Great Plains, Atmos. Meas. Tech. Discuss., 5, 7187-7222, doi:10.5194/amtd-5-7187-2012, 2012.

Buck, A. L.: New Equations for Computing Vapor Pressure and Enhancement Factor, J. Appl. Meteorol., 20, 1527-1532, doi:10.1175/1520-0450(1981)020<1527:NEFCVP>2.0.CO;2, 1981.

Cambaliza, M. O. L., Shepson, P., Stirm, B., Sweeney, C., Turnbull, J., Karion, A., Davis, K., Lauvaux, T., Richardson, S., Miles, N., and Svetanoff, R.: Quantification of emissions from methane sources in Indianapolis using an aircraft-based platform, Abstr. Pap. Am. Chem. S., Publ. No. '473, 2011.

Chen, H., Winderlich, J., Gerbig, C., Hoefer, A., Rella, C. W., Crosson, E. R., Van Pelt, A. D., Steinbach, J., Kolle, O., Beck, V., Daube, B. C., Gottlieb, E. W., Chow, V. Y., Santoni, G. W., and Wofsy, S. C.: High-accuracy continuous airborne measurements of greenhouse gases $\left(\mathrm{CO}_{2}\right.$ and $\left.\mathrm{CH}_{4}\right)$ using the cavity ringdown spectroscopy (CRDS) technique, Atmos. Meas. Tech., 3, 375-386, doi:10.5194/amt-3-375-2010, 2010.

Chen, H., Karion, A., Rella, C. W., Winderlich, J., Gerbig, C., Filges, A., Newberger, T., Sweeney, C., and Tans, P. P.: Accurate measurements of carbon monoxide in humid air using the cavity ring-down spectroscopy (CRDS) technique, Atmos. Meas. Tech. Discuss., 5, 6493-6517, doi:10.5194/amtd-5-6493-2012, 2012 a.

Chen, H., Winderlich, J., Gerbig, C., Katrynski, K., Jordan, A., and Heimann, M.: Validation of routine continuous airborne $\mathrm{CO}_{2}$ observations near the Bialystok Tall Tower, Atmos. Meas. Tech., 5, 873-889, doi:10.5194/amt-5-873-2012, 2012b.

Conway, T. J., Steele, L. P., and Novelli, P. C.: Correlations among atmospheric $\mathrm{CO}_{2}, \mathrm{CH}_{4}$ and $\mathrm{CO}$ in the Arctic, March 1989, Atmos. Environ. A-Gen., 27, 2881-2894, 1993.

Crosson, E. R.: A cavity ring-down analyzer for measuring atmospheric levels of methane, carbon dioxide, and water vapor, Appl Phys. B-Lasers O., 92, 403-408, doi:10.1007/s00340-008-3135y, 2008

Daube, B. C., Boering, K. A., Andrews, A. E., and Wofsy, S. C.: A high-precision fast-response airborne $\mathrm{CO}_{2}$ analyzer for in situ sampling from the surface to the middle stratosphere, J. Atmos. Ocean. Tech., 19, 1532-1543, 2002.

Dlugokencky, E. J., Myers, R. C., Lang, P. M., Masarie, K. A., Crotwell, A. M., Thoning, K. W., Hall, B. D., Elkins, J. W., and Steele, L. P.: Conversion of NOAA atmospheric dry air $\mathrm{CH}_{4}$ mole fractions to a gravimetrically prepared standard scale, J. Geophys. Res. Atmos., 110, D18306, doi:10.1029/2005JD006035, 2005. 
Forster, P., Ramaswamy, V., Artaxo, P., Berntsen, T., Betts, R., Fahey, D. W., and Haywood, J.: Changes in Atmospheric Constituents and in Radiative Forcing, in: Climate Change 2007: The Physical Science Basis, Contribution of Working Group I to the Fourth Assessment Report of the IPCC, edited by: Solomon, S., Qin, D., Manning, M., Chen, Z., Marquis, M., Averyt, K. B., Tignor, M., and Miller, H. L., Cambridge University Press, Cambridge, United Kingdom and New York, NY, USA, 2007.

Goff, J. A.: Saturation pressure of water on the new Kelvin temperature scale, Transactions of the American Society of Heating and Ventilating Engineers, Murray Bay, Quebec, Canada, 1957.

Hall, B. D., Dutton, G. S., and Elkins, J. W.: The NOAA nitrous oxide standard scale for atmospheric observations, J. Geophys. Res., 112, doi:10.1029/2006jd007954, 2007.

Harriss, R. C., Sachse, G. W., Hill, G. F., Wade, L., Bartlett, K. B., Collins, J. E., Steele, L. P., and Novelli, P. C.: Carbon-monoxide and methane in the North-American Arctic and sub-Arctic troposphere - July-August 1988, J. Geophys. Res.-Atmos., 97, 16589-16599, 1992.

Harriss, R. C., Sachse, G. W., Collins, J. E., Wade, L., Bartlett, K. B., Talbot, R. W., Browell, E. V., Barrie, L. A., Hill, G. F., and Burney, L. G.: Carbon-monoxide and methane over Canada - July-August 1990, J. Geophys. Res.-Atmos., 99, 1659-1669, 1994.

Jacob, D. J., Crawford, J. H., Maring, H., Clarke, A. D., Dibb, J. E., Emmons, L. K., Ferrare, R. A., Hostetler, C. A., Russell, P. B., Singh, H. B., Thompson, A. M., Shaw, G. E., McCauley, E., Pederson, J. R., and Fisher, J. A.: The Arctic Research of the Composition of the Troposphere from Aircraft and Satellites (ARCTAS) mission: design, execution, and first results, Atmos. Chem. Phys., 10, 5191-5212, doi:10.5194/acp-10-5191-2010, 2010.

Jorgenson, M. T., Racine, C. H., Walters, J. C., and Osterkamp, T. E.: Permafrost degradation and ecological changes associated with a warming climate in central Alaska, Climatic Change, 48, 551-579, 2001.

Keyser, A. R., Kimball, J. S., Nemani, R. R., and Running, S. W.: Simulating the effects of climate change on the carbon balance of North American high-latitude forests, Glob. Change Biol., 6, 185-195, 2000.

Kort, E. A., Wofsy, S. C., Daube, B. C., Diao, M., Elkins, J. W., Gao, R. S., Hintsa, E. J., Hurst, D. F., Jimenez, R., Moore, F. L., Spackman, J. R., and Zondlo, M. A.: Atmospheric observations of Arctic Ocean methane emissions up to 82 degrees north, Nat. Geosci., 5, 318-321, doi:10.1038/ngeo1452, 2012.

Machida, T., Matsueda, H., Sawa, Y., Nakagawa, Y., Hirotani, K., Kondo, N., Goto, K., Nakazawa, T., Ishikawa, K., and Ogawa, T.: Worldwide Measurements of Atmospheric $\mathrm{CO}_{2}$ and Other Trace Gas Species Using Commercial Airlines, J. Atmos. Ocean. Tech., 25, 1744-1754, doi:10.1175/2008jtecha1082.1, 2008.

Martins, D. K., Sweeney, C., Stirm, B. H., and Shepson, P. B.: Regional surface flux of $\mathrm{CO}_{2}$ inferred from changes in the advected $\mathrm{CO}_{2}$ column density, Agr. Forest Meteorol., 149, 1674-1685, doi:10.1016/j.agrformet.2009.05.005, 2009.

Mays, K. L., Shepson, P. B., Stirm, B. H., Karion, A., Sweeney, C., and Gurney, K. R.: Aircraft-based measurements of the carbon footprint of Indianapolis, Environ. Sci. Technol., 43, 7816-7823, doi:10.1021/es901326b, 2009.

McGuire, A. D., Anderson, L. G., Christensen, T. R., Dallimore, S., Guo, L. D., Hayes, D. J., Heimann, M., Lorenson, T. D., Mac- donald, R. W., and Roulet, N.: Sensitivity of the carbon cycle in the Arctic to climate change, Ecol. Monogr., 79, 523-555, 2009.

Miles, N. L., Richardson, S. J., Davis, K. J., Lauvaux, T., Andrews, A. E., West, T. O., Bandaru, V., and Crosson, E. R.: Large amplitude spatial and temporal gradients in atmospheric boundary layer $\mathrm{CO}_{2}$ mole fractions detected with a tower-based network in the US upper Midwest, J. Geophys. Res., 117, G01019, doi:10.1029/2011jg001781, 2012.

Miller, J. B., Gatti, L. V., d'Amelio, M. T. S., Crotwell, A. M., Dlugokencky, E. J., Bakwin, P., Artaxo, P., and Tans, P. P.: Airborne measurements indicate large methane emissions from the eastern Amazon basin, Geophys. Res. Lett., 34, L10809, doi:10.1029/2006g1029213, 2007.

Montzka, S. A., Myers, R. C., Butler, J. H., Elkins, J. W., and Cummings, S. O.: Global tropospheric distribution and calibration scale of HCFC-22, Geophys. Res. Lett., 20, 703-706, 1993.

Nara, H., Tanimoto, H., Tohjima, Y., Mukai, H., Nojiri, Y., Katsumata, K., and Rella, C. W.: Effect of air composition $\left(\mathrm{N}_{2}, \mathrm{O}_{2}, \mathrm{Ar}\right.$, and $\left.\mathrm{H}_{2} \mathrm{O}\right)$ on $\mathrm{CO}_{2}$ and $\mathrm{CH}_{4}$ measurement by wavelength-scanned cavity ring-down spectroscopy: calibration and measurement strategy, Atmos. Meas. Tech., 5, 2689-2701, doi:10.5194/amt-5-2689-2012, 2012.

Neff, D.: The Programmable Flask Package Air Sampling System, in preparation, 2013.

Novelli, P. C.: Reanalysis of tropospheric CO trends: Effects of the 1997-1998 wildfires, J. Geophys. Res., 108, 13109-13121, doi:10.1029/2002jd003031, 2003.

Novelli, P. C., Elkins, J. W., and Steele, L. P.: The development and evaluation of a gravimetric reference scale for measurements of atmospheric carbon monoxide, J. Geophys. Res.-Atmos., 96, 13109-13121, doi:10.1029/91jd01108, 1991.

O'Connor, F. M., Boucher, O., Gedney, N., Jones, C. D., Folberth, G. A., Coppell, R., Friedlingstein, P., Collins, W. J., Chappellaz, J., Ridley, J., and Johnson, C. E.: Possible role of wetlands, permafrost, and methane hydrates in the methane cycle under future climate change: A review, Rev. Geophys., 48, RG4005, doi:10.1029/2010rg000326, 2010.

O'Shea, S. J., Bauguitte, S. J.-B., Gallagher, M. W., Lowry, D., and Percival, C. J.: Development of a cavity enhanced absorption spectrometer for airborne measurements of $\mathrm{CH}_{4}$ and $\mathrm{CO}_{2}$, Atmos. Meas. Tech. Discuss., 6, 1-41, doi:10.5194/amtd-6-1-2013, 2013.

Paris, J. D., Ciais, P., Nedelec, P., Ramonet, M., Belan, B. D., Arshinov, M. Y., Golitsyn, G. S., Granberg, I., Stohl, A., Cayez, G., Athier, G., Boumard, F., and Cousin, J. M.: The YAK-AEROSIB transcontinental aircraft campaigns: new insights on the transport of $\mathrm{CO}_{2}$, CO and O-3 across Siberia, Tellus B, 60, 551-568, doi:10.1111/j.1600-0889.2008.00369.x, 2008.

Rella, C. W., Chen, H., Andrews, A. E., Filges, A., Gerbig, C., Hatakka, J., Karion, A., Miles, N. L., Richardson, S. J., Steinbacher, M., Sweeney, C., Wastine, B., and Zellweger, C.: High accuracy measurements of dry mole fractions of carbon dioxide and methane in humid air, Atmos. Meas. Tech. Discuss., 5, 5823-5888, doi:10.5194/amtd-5-5823-2012, 2012.

Richardson, S. J., Miles, N. L., Davis, K. J., Crosson, E. R., Rella, C. W., and Andrews, A. E.: Field Testing of Cavity Ring-Down Spectroscopy Analyzers Measuring Carbon Dioxide and Water Vapor, J. Atmos. Ocean. Tech., 29, 397-406, doi:10.1175/jtechd-11-00063.1, 2012. 
Sweeney, C., Karion, A., Wolter, S., Neff, D., Higgs, J. A., Heller, M., Guenther, D., Miller, B. R., Montzka, S. A., Miller, J. B., Conway, T. J., Dlugokencky, E., Novelli, P. C., Masarie, K., Oltman, S., and Tans, P.: Carbon dioxide climatology of the NOAA/ESRL Greenhouse Gas Aircraft Network, in preparation, 2013.

Turnbull, J. C., Karion, A., Fischer, M. L., Faloona, I., Guilderson, T., Lehman, S. J., Miller, B. R., Miller, J. B., Montzka, S., Sherwood, T., Saripalli, S., Sweeney, C., and Tans, P. P.: Assessment of fossil fuel carbon dioxide and other anthropogenic trace gas emissions from airborne measurements over Sacramento, California in spring 2009, Atmos. Chem. Phys., 11, 705-721, doi:10.5194/acp-11-705-2011, 2011.

Vaughn, B. H., Ferretti, D. F., Miller, J. B., and White, J. W. C.: Stable isotope measurements of atmospheric $\mathrm{CO}_{2}$ and $\mathrm{CH}_{4}$, in: Handbook of stable isotope analytical techniques, Elsevier BV, Amsterdam, The Netherlands, 2004.

Vay, S. A., Choi, Y., Vadrevu, K. P., Blake, D. R., Tyler, S. C., Wisthaler, A., Hecobian, A., Kondo, Y., Diskin, G. S., Sachse, G. W., Woo, J. H., Weinheimer, A. J., Burkhart, J. F., Stohl, A., and Wennberg, P. O.: Patterns of $\mathrm{CO}_{2}$ and radiocarbon across high northern latitudes during International Polar Year 2008, J. Geophys. Res., 116, D14301, doi:10.1029/2011jd015643, 2011.
Winderlich, J., Chen, H., Gerbig, C., Seifert, T., Kolle, O., Lavrič, J. V., Kaiser, C., Höfer, A., and Heimann, M.: Continuous lowmaintenance $\mathrm{CO}_{2} / \mathrm{CH}_{4} / \mathrm{H}_{2} \mathrm{O}$ measurements at the Zotino Tall Tower Observatory (ZOTTO) in Central Siberia, Atmos. Meas. Tech., 3, 1113-1128, doi:10.5194/amt-3-1113-2010, 2010.

Wofsy, S. C., Team, H. S., Cooperating Modellers, T., and Satellite, T.: HIAPER Pole-to-Pole Observations (HIPPO): finegrained, global-scale measurements of climatically important atmospheric gases and aerosols, Philos. T. Roy. Soc. A, 369, 2073 2086, doi:10.1098/rsta.2010.0313, 2011.

Xueref-Remy, I., Messager, C., Filippi, D., Pastel, M., Nedelec, P., Ramonet, M., Paris, J. D., and Ciais, P.: Variability and budget of $\mathrm{CO}_{2}$ in Europe: analysis of the CAATER airborne campaigns - Part 1: Observed variability, Atmos. Chem. Phys., 11, 56555672, doi:10.5194/acp-11-5655-2011, 2011.

Zhao, C. L. and Tans, P. P.: Estimating uncertainty of the WMO mole fraction scale for carbon dioxide in air, J. Geophys. Res., 111, D08S09, doi:10.1029/2005jd006003, 2006. 